\title{
Surges, atmospheric pressure and wind change and flooding probability on the Atlantic coast of France
}

\author{
Paolo Antonio PIRAZZOLI*
}

CNRS, laboratoire de géographie physique, 1, place Aristide-Briand, 92195 Meudon cedex, France

Received 4 October 1999; revised 20 December 1999; accepted 22 December 1999

\begin{abstract}
A statistical study of hourly tide-gauge records at Saint-Gildas, Saint-Nazaire, Port Tudy, Brest, Le Conquet and Roscoff, as well of three-hourly wind and air pressure records at Belle Ile and Ouessant over the last 50 years, has made possible the definition of the main meteorological factors which are associated with the development of positive or negative surges. Recent changes in these meteorological factors indicate that atmospheric depressions and strong surge winds are becoming less frequent and that the ongoing trends of climate variability show a decrease in the frequency and hence the gravity of coastal flooding. However the highest sea surges of the last decades did not occur at the time of spring high tide. There is a significant statistical probability that coastal flooding reaching higher elevations than in the recent past may occur in the near future, in spite of the improvement of climatic trends. (C) 2000 Ifremer/CNRS/IRD/Éditions scientifiques et médicales Elsevier SAS
\end{abstract}

\section{surge / wind / climate variability / flooding probability / French Atlantic coast}

Résumé - Surcotes et décotes, variations de pression atmosphérique et de vent et probabilité d'inondation sur la côte atlantique française. Une étude statistique des enregistrements marégraphiques horaires à Saint-Gildas, SaintNazaire, Port Tudy, Brest, Le Conquet et Roscoff, ainsi que des observations trihoraires du vent et de la pression atmosphérique à Belle-Ile et à Ouessant, au cours des cinquante dernières années, permet de caractériser les principaux facteurs météorologiques qui sont associés à la formation de surcotes ou de décotes marines. Les variations récentes de ces facteurs météorologiques montrent que les dépressions atmosphériques et les vents forts de surcote deviennent moins fréquents et que les tendances de variabilité climatique en cours sont potentiellement favorables à une diminution de la fréquence et de la gravité des inondations littorales. Cependant les surcotes marines les plus élevées des dernières décennies ont rarement coïncidé avec une pleine mer de vives-eaux. Il est donc statistiquement probable que, malgré l'amélioration des tendances climatiques, des inondations littorales atteignant des niveaux plus élevés que dans le passé récent, se produisent dans un avenir proche. (C) 2000 Ifremer/CNRS/IRD/Éditions scientifiques et médicales Elsevier SAS

\section{surcote et décote / vent / variabilité climatique / probabilité d'inondation / côte atlantique française}

\section{INTRODUCTION}

A sea surge corresponds to the difference between the observed sea level and the predicted tidal level at the

\footnotetext{
* Correspondence and reprints:

E-mail address: pirazzol@cnrs-bellevue.fr (P.A. PIRAZZOLI).
}

same time. Surges are mainly the response of sea level to meteorological forcing (atmospheric pressure and winds). Positive surges occurring at high tide often produce coastal flooding. When atmospheric pressure increases locally, water must outflow from that region to achieve hydrostatic balance of the water plus air column. If it is assumed that there are no constraints 
in the water flow and the response is instantaneous, then it is found that $1 \mathrm{hPa}$ of increase (decrease) of atmospheric pressure causes $1 \mathrm{~cm}$ decrease (increase) of the sea level. In coastal areas and especially in partially closed seas (like the Channel or the Mediterranean), because of the restrictions in the flow of water, the response of sea level to atmospheric forcing is only partially hydrostatic.

Wind is also an important parameter that causes piling up of water at the coasts. The onshore component of the wind has been found to be consistent with the sea level in areas with extensive continental shelf in the open ocean. The integrated effect of the atmospheric parameters, the tides and the (potentially significant) non-linear interaction between them can be measured by tide-gauges. Tide-gauge measurements are also prone to exhibit seasonal, interannual and interdecadal changes in the relative sea level.

In the context of climate change the major question that has been so far considered is whether it will lead to coastal flooding due to an overall increase of global sea level. Values between 0.5 and $2.4 \mathrm{~mm} \cdot \mathrm{yr}^{-1}$ have been proposed for the global sea-level rise during the last century on the basis of the longest time series available, without the significant acceleration which might be expected if the measured trend was modified due to the influence of industrialisation [11]. According to Topex-Poseidon satellite observations, the average global sea-level rise since 1992 can be estimated to $2.0 \mathrm{~mm} \cdot \mathrm{yr}^{-1}$ [4].

Nevertheless climate change may be localised and not necessarily reflected by mean values of climatic parameters. For sea level studies in particular it is more useful to know whether an area endangered by flooding is subject to increased winds or deeper atmospheric lows rather than approaching the problem through the global or even local mean sea level trend due to other factors. Even a systematic change in the direction of the locally prevailing winds may increase the number or the size of floods and result in increased damage. It is in this context that the distribution of the extremes of meteorological parameters and their reflection in sea level becomes increasingly important.

In macrotidal areas, the impacts of a surge on the coast will depend of course on the tide level at the moment of the surge peak. Impacts will be at a

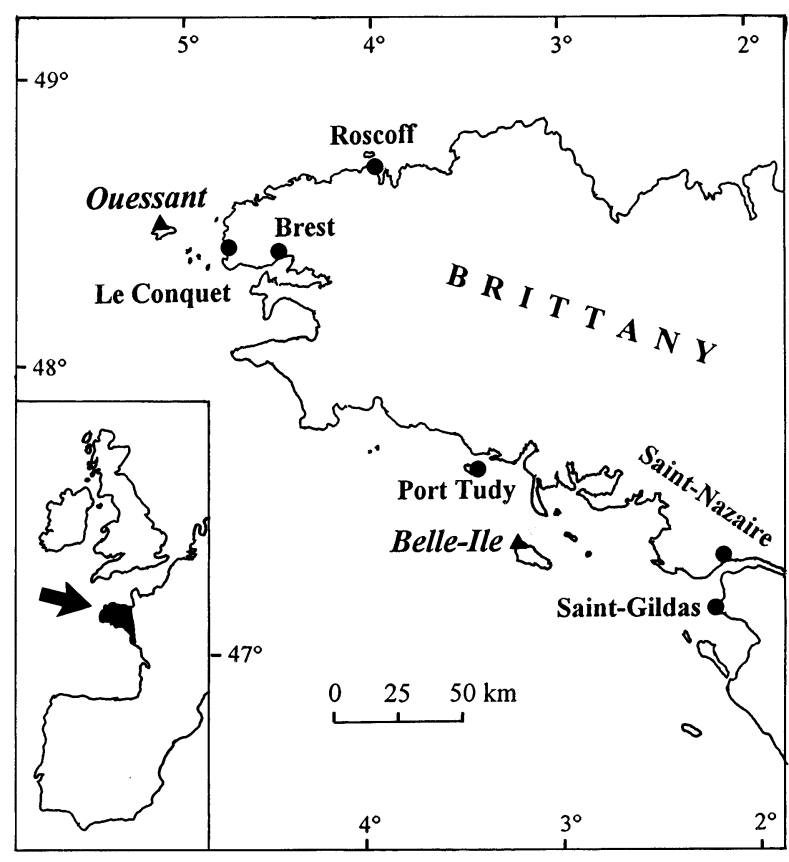

Figure 1. Location map: tide gauges (dots) and meteorological stations (triangles).

maximum for positive surges occurring at spring high tide (at perigean spring high tide in the Bay of Fundy [10], which experiences the highest tides in the world), whereas even exceptional surges may escape notice when they occur at lower tide levels. Pugh and Vassie [12] have shown that surges and tides are statistically independent. It is possible to calculate their probabilities and trends separately using hourly tide records.

For the computation and statistical analysis of surges, digitised tidal and meteorological records are necessary. In recent years, such digitised records have become available in many places [13]. Some timeseries of hourly tide-gauge records go back to the early 1950 s, or even earlier. Three-hourly meteorological data have been collected since the late 1940s or the early 1950s in certain airports and meteorological stations. Generally joint analysis of forcing conditions and surges are only viable post-1950. These series are long enough to estimate trends in variation.

In this paper tide-gauge and meteorological data of the last few decades will by analysed along the northern part of the Atlantic coast of France, between Saint-Gildas and Roscoff (figure 1). The study includes the distribution of surges, the analysis of cer- 
Table I. List of tidal records available.

\begin{tabular}{lccc}
\hline Tide-gauge station & Number of hourly records & Missing data (\%) & Number of equivalent full years available \\
\hline Saint-Gildas (1962-1991) & 203,771 & 29 & 23.27 \\
Saint-Nazaire 1965-1988) & 183,543 & 15 & 20.96 \\
Port Tudy (1966-1995) & 178,212 & 48 & 20.34 \\
Brest $(1860-1995)^{\mathrm{a}}$ & $1,058,822$ & 9 & 105.4 \\
Brest $(1953-1995)^{\mathrm{a}}$ & 367,840 & 2 & 42.0 \\
Le Conquet (1971-1994) & 190,540 & 10 & 19.52 \\
Roscoff $(1973-1995)^{\mathrm{a}}$ & 176,967 & 14 & 18.13 \\
\hline
\end{tabular}

a The data for the year 1995 are incomplete, ending in January at Port Tudy and Roscoff, and in early April at Brest.

tain meteorological factors (wind and atmospheric pressure) controlling them and the evolving trends of these factors during the last decades. Finally, the probability of coastal flooding is also analysed. The study of geostrophic factors (which are not available at coastal sites) and of wave height (for which records are scarce), which also influence surges, have provisionally not been considered.

\section{DATA}

Meteorological records have been studied mainly at two stations: Belle Ile (from 1961 to 1997) and Ouessant (from 1951 to 1997). Digitised records were available from Météo-France and consist of threehourly values of air pressure and of wind (average of a ten-minute run every three hours of record) direction and velocity. Daily data on maximum wind gusts have also been considered.

Hourly tide-gauge records, provided by Service $H y$ drographique et Océanographique de la Marine (SHOM), have been studied at Saint-Gildas, SaintNazaire, Port Tudy, Brest, Le Conquet and Roscoff (figure 1). The data available are summarised in table $I$.

At each station, hourly values of the astronomical tide have been obtained using the Predit software produced by SHOM. After deduction of MSL variations (for the method used, see [3]) hourly surge values were computed using the Surcote software (produced by M. Ba for CNRS-UMR 8591, following the Statistical Analysis System (SAS) language and procedures). For Saint-Nazaire, Saint-Gildas and Le Conquet, preliminary data processing had been carried out by Jardin and Oden [6].
A further step in the analysis consisted of identifying and rejecting clearly anomalous data (resulting from obvious digitising errors, or from incorrect operating of the recording device). Frequent anomalies are oscillations of surge values with a period similar to that of the tide. It has been first verified, using appropriate mathematical filtering methods provided by A. Tomasin (University of Venice), that most of these oscillations do not correspond to seiches (at least with periods between 4 and $28 \mathrm{~h}$ ); they also cannot be seiches because the amplitude of these oscillations often increases gradually in time and may disappear suddenly, independently of meteorological events whereas seiches, which are generally triggered by short disturbances in the air-water equilibrium, usually appear suddenly and attenuate gradually (see e.g. [14]), and also because no similar oscillations were observed at nearby tide-gauges. Such oscillations have therefore been interpreted as due to chronological mis-adjustment of the tide gauge; in most cases the corresponding surge values were considered as missing data, especially for peaks and troughs of apparent oscillations exceeding $\pm 30 \mathrm{~cm}$.

\section{TIDAL HEIGHTS}

The hourly distribution of astronomical and recorded tide levels and of surges has been analysed at each tidal station. Between Saint-Gildas and Roscoff, the astronomical tidal range varies between $547 \mathrm{~cm}$ (Port Tudy) and $946 \mathrm{~cm}$ (Roscoff), whereas maximum recorded surges range from $98 \mathrm{~cm}$ (Roscoff) to $173 \mathrm{~cm}$ (Saint-Nazaire) and the maximum recorded negative surges from $-57 \mathrm{~cm}$ (Port Tudy) to $-82 \mathrm{~cm}$ (Saint-Nazaire). The 50th recorded hourly surge is generally at least $70 \mathrm{~cm}$ (table II). 
Table II. Extreme surge levels compared to extreme tide levels.

\begin{tabular}{|c|c|c|c|c|c|c|c|c|c|c|}
\hline $\begin{array}{l}\text { Tide-gauge } \\
\text { station }\end{array}$ & $\begin{array}{l}\text { Max. } \\
\text { recorded } \\
\text { surge } \\
(\mathrm{cm})\end{array}$ & $\begin{array}{l}10 \text { th } \\
\text { surge } \\
(\mathrm{cm})\end{array}$ & $\begin{array}{l}50 \text { th } \\
\text { surge } \\
(\mathrm{cm})\end{array}$ & $\begin{array}{l}\text { Max. } \\
\text { recorded } \\
\text { tide level } \\
(\mathrm{cm})^{\mathrm{a}}\end{array}$ & $\begin{array}{l}\text { Max. } \\
\text { astronomical } \\
\text { tide level } \\
(\mathrm{cm})^{\mathrm{a}}\end{array}$ & $\begin{array}{l}\text { Difference (max. } \\
\text { recorded - max. } \\
\text { astronomical) } \\
(\mathrm{cm})\end{array}$ & $\begin{array}{l}\text { Max. } \\
\text { recorded } \\
\text { negative } \\
\text { surge }(\mathrm{cm})\end{array}$ & $\begin{array}{l}\text { Min. recorded } \\
\text { tide level }(\mathrm{cm})^{\mathrm{a}}\end{array}$ & $\begin{array}{l}\text { Min. astro- } \\
\text { nomical tide } \\
\text { level }(\mathrm{cm})^{\mathrm{a}}\end{array}$ & $\begin{array}{l}\text { Difference }(\mathrm{min} \text {. } \\
\text { recorded }-\mathrm{min} . \\
\text { astronomical) } \\
(\mathrm{cm})\end{array}$ \\
\hline & $\mathrm{a}$ & $\mathrm{b}$ & $\mathrm{c}$ & d & $\mathrm{e}$ & $\mathrm{f}=\mathrm{d}-\mathrm{e}$ & g & $\mathrm{h}$ & $\mathrm{i}$ & $\mathrm{j}=\mathrm{h}-\mathrm{i}$ \\
\hline Saint-Gildas & 147 & 92 & 76 & 621 & 599 & 22 & -71 & -32 & -17 & -15 \\
\hline Saint-Nazaire & 173 & 123 & 91 & 634 & 609 & 25 & -82 & -47 & -10 & -37 \\
\hline Port Tudy & 129 & 85 & 73 & 599 & 573 & 26 & -57 & +2 & +26 & -24 \\
\hline Brest & 144 & 99 & 89 & 860 & 828 & 32 & -75 & +36 & +66 & -30 \\
\hline Le Conquet & 143 & 92 & 70 & 808 & 792 & 16 & -60 & +23 & +57 & -34 \\
\hline Roscoff & 98 & 85 & 69 & 994 & 973 & 21 & -73 & +9 & +27 & -18 \\
\hline
\end{tabular}

${ }^{a}$ In relation to local datums.
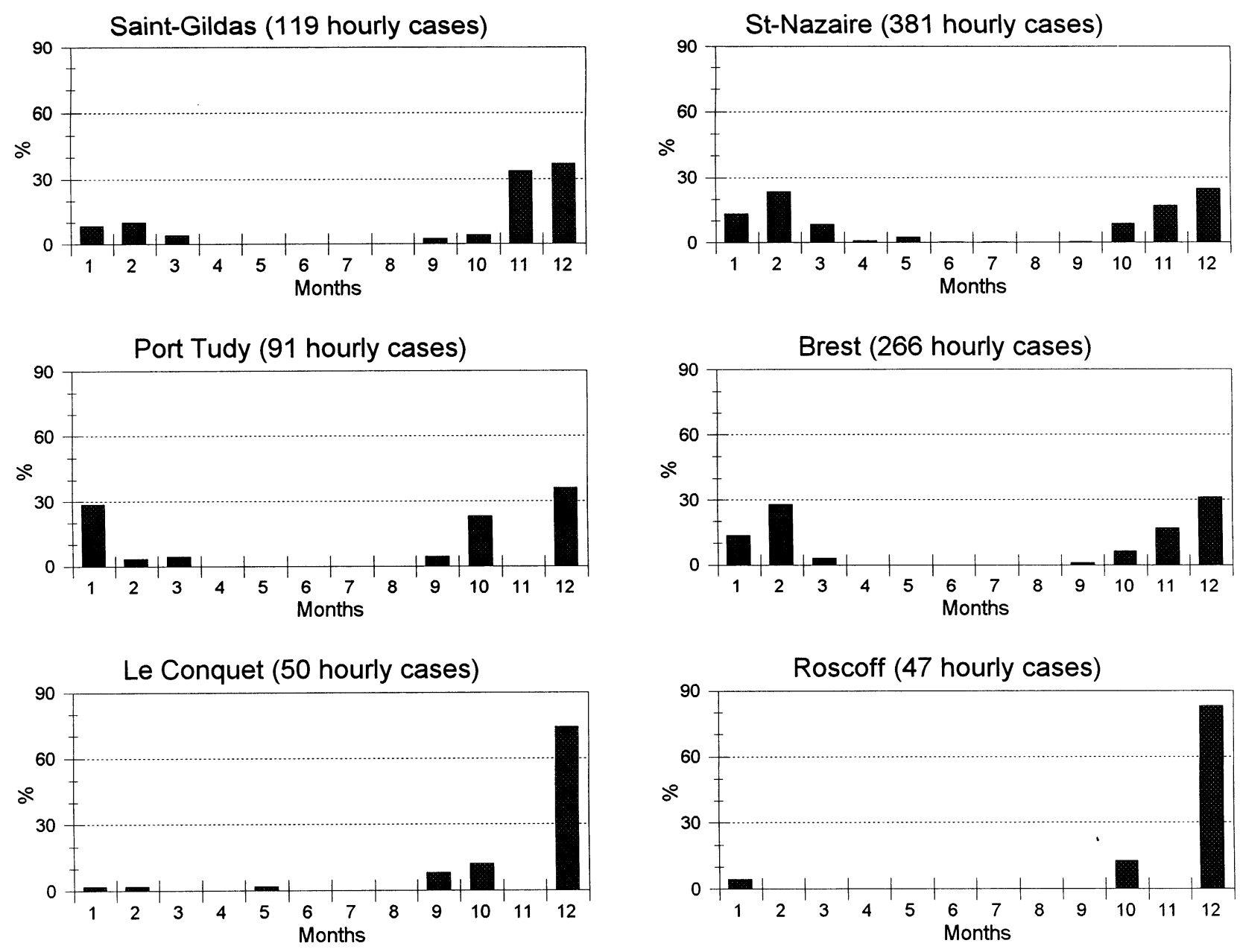

Figure 2. Monthly distribution of positive surges $\geq 70 \mathrm{~cm}$. 
Most surges occur during storms between October and February and are most frequent in December (especially at Le Conquet and Roscoff) (figure 2). Also most negative surges occur during the cold season, especially between November and March (figure 3).

With the exception of Brest, most digitised records are still too short or incomplete to deduce long-term or even interdecadal variability. At Brest, in a previous study [3], Bouligand and Pirazzoli have shown that the highest surges (annual maxima and 99th percentiles) indicate an increasing trend if all the data (1860-1994) are considered, but a decreasing trend for the most recent period (1953-1994). Similar decreasing trends since 1953 can be confirmed for most
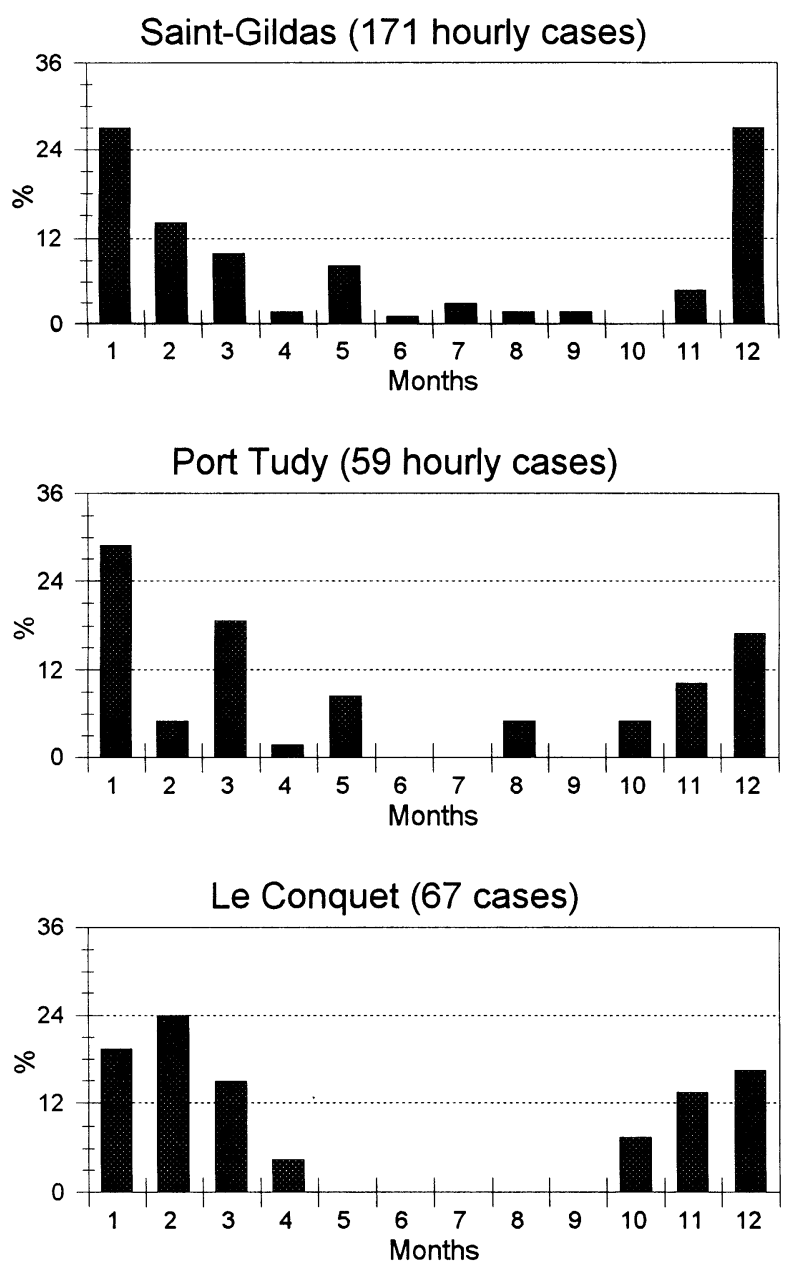

Figure 3. Monthly distribution of negative surges $\leq-40 \mathrm{~cm}$. categories of surges and are statistically significant at the $68 \%$ confidence level $^{1}$ for surges $\geq 20, \geq 30$ and $\geq 40 \mathrm{~cm}$ (figure 4). If the analysis is starting only in 1961 (to avoid the exceptionally high number of

\footnotetext{
${ }^{1}$ In the following, trends are determined mainly as regression lines, the slopes of which are compared to the standard deviation $( \pm \sigma)$, in order to estimate their statistical significance. As is already known, $\sigma$ gives the likelihood of the real slope with $68 \%$ probability (or $1.96 \sigma$ gives $95 \% ; 2.58 \sigma$ gives $99 \%$ ). As a good confidence is required for a positive/negative trend, as soon as the slope turns out to be positive/negative, and $>\sigma$ (or $1.96 \sigma$, or $2.58 \sigma$ ), one can trust that a clear tendency exists with $68 \%$ (or $95 \%$, or $99 \%$ ). According to criteria of trend detection used in IPCC estimations, it will be assumed here that with a confidence $>99 \%$ a trend will be virtually certain, with $90-99 \%$ very likely, 66-90\% likely, $33-66 \%$ possible, $10-33 \%$ unlikely, $0.01-10 \%$ very unlikely and $<0.01 \%$ virtually impossible.
}
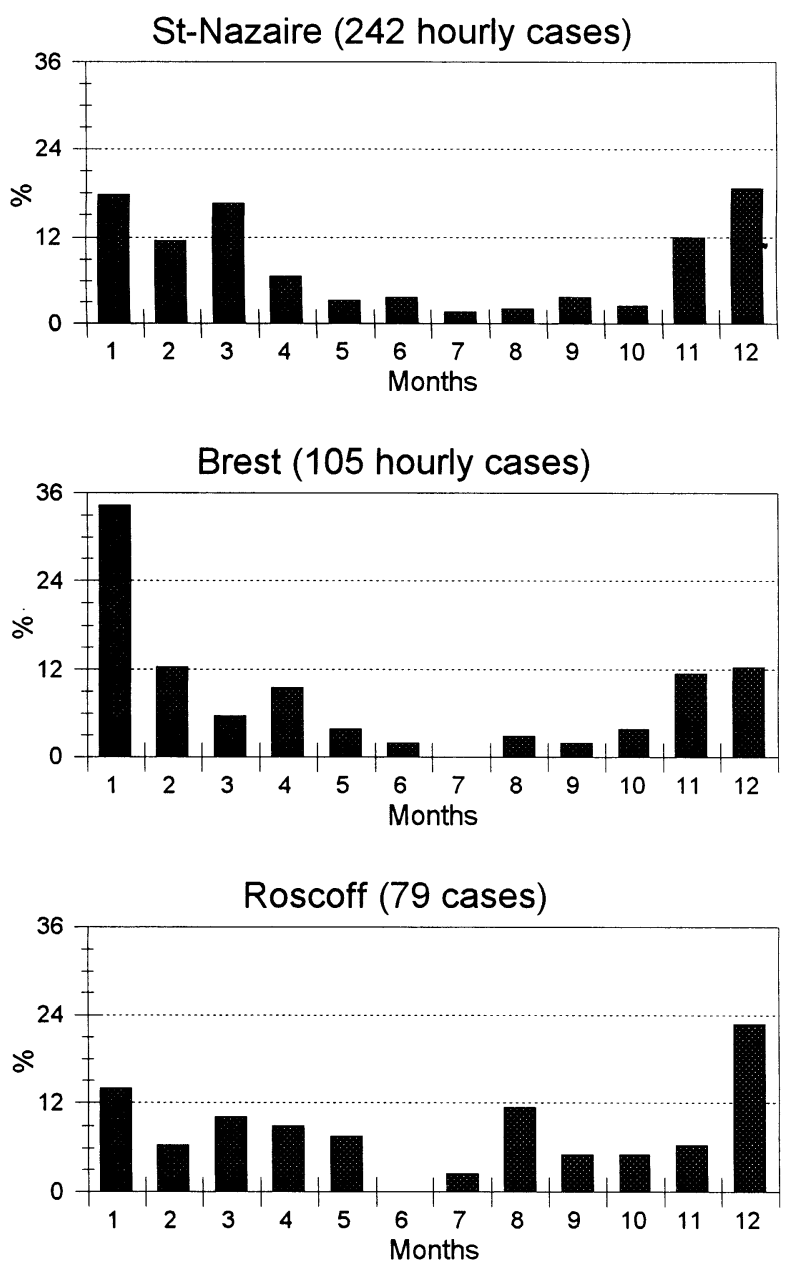
occurrences in 1960), similar more or less likely negative trends would systematically be found $(-8.70$ \pm 7.89 occurrences per year for surges $\geq 10 \mathrm{~cm}$; $-4.35 \pm 4.57$ for surges $\geq 20 \mathrm{~cm} ;-2.68 \pm 2.62$ for surges $\geq 30 \mathrm{~cm}$ and $-1.25 \pm 1.33$ for surges $\geq 40$ $\mathrm{cm}$ ), thus confirming the degree of likelihood of the trends observed since 1953 .

The main meteorological situations which produce strong surges at Brest have been described [1]. Surges are usually caused by storms; at the time of surges $\geq 70 \mathrm{~cm}$, surface air pressure at Belle-Ile is usually much lower than the local average value at sea level (about $1017 \mathrm{hPa}$ ) or even than the world average value (1013 hPa) (figure 5) and similar depression patterns predominate also at Ouessant. Conversely, negative surges are caused by atmospheric air pressure generally higher than average (figure 6).

While high and average surface air pressure show similar ranges of variation at Belle-Ile and Ouessant, atmospheric depressions tend to become deeper at Ouessant, where the first air pressure percentile (986.9 $\mathrm{hPa}$, average between 1961 and 1997) is $3.5 \mathrm{hPa}$ lower than the first percentile at Belle-Ile during the same period $(990.4 \mathrm{hPa})$.

The frequency and duration of atmospheric depressions tend to decrease, at Ouessant as well as at Belle-Ile. In figure 7 the data refer to air pressure

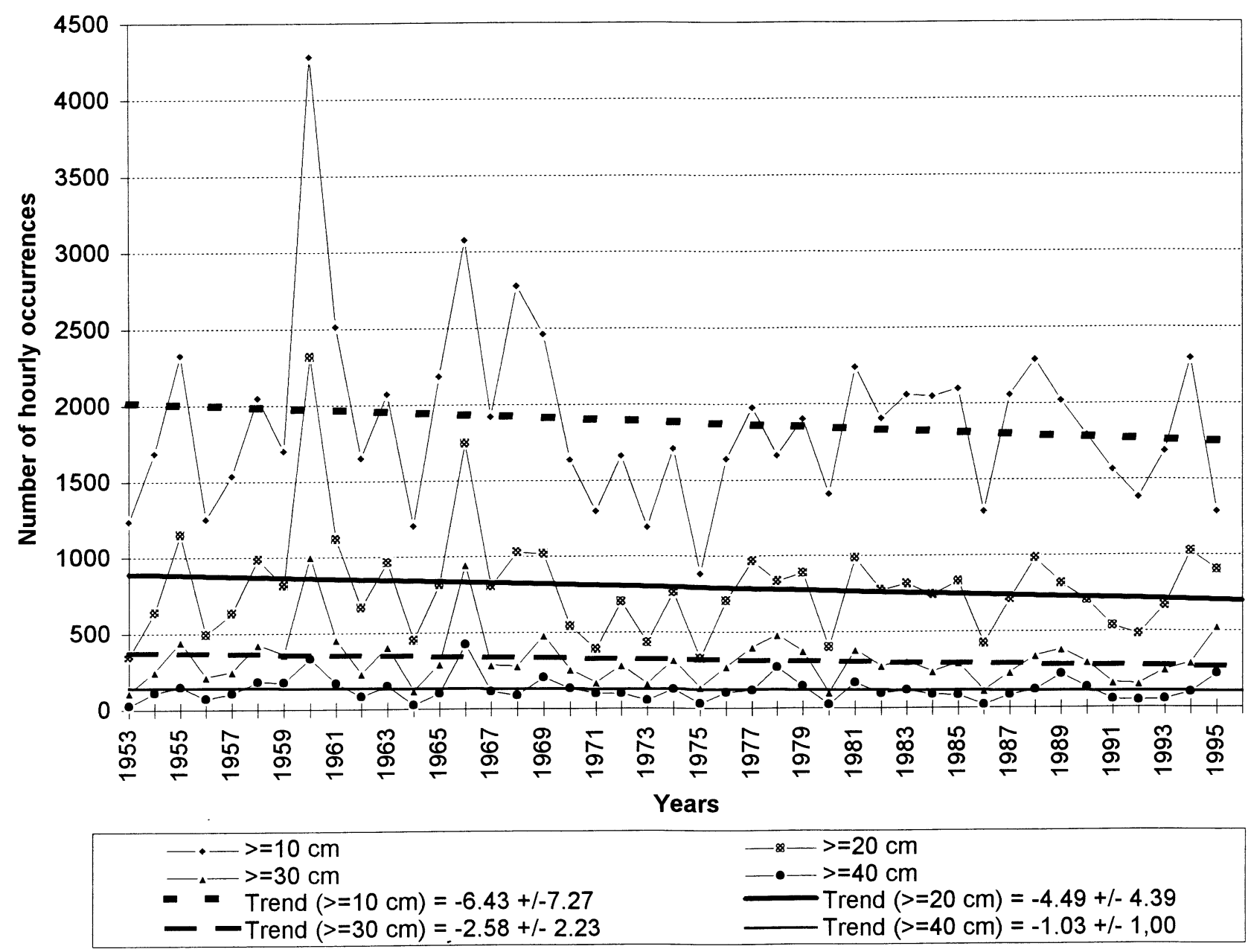

Figure 4. Frequency of positive surges $\geq 10 \mathrm{~cm}, \geq 20 \mathrm{~cm}, \geq 30 \mathrm{~cm}$ and $\geq 40 \mathrm{~cm}$ at Brest (1953-1995). 


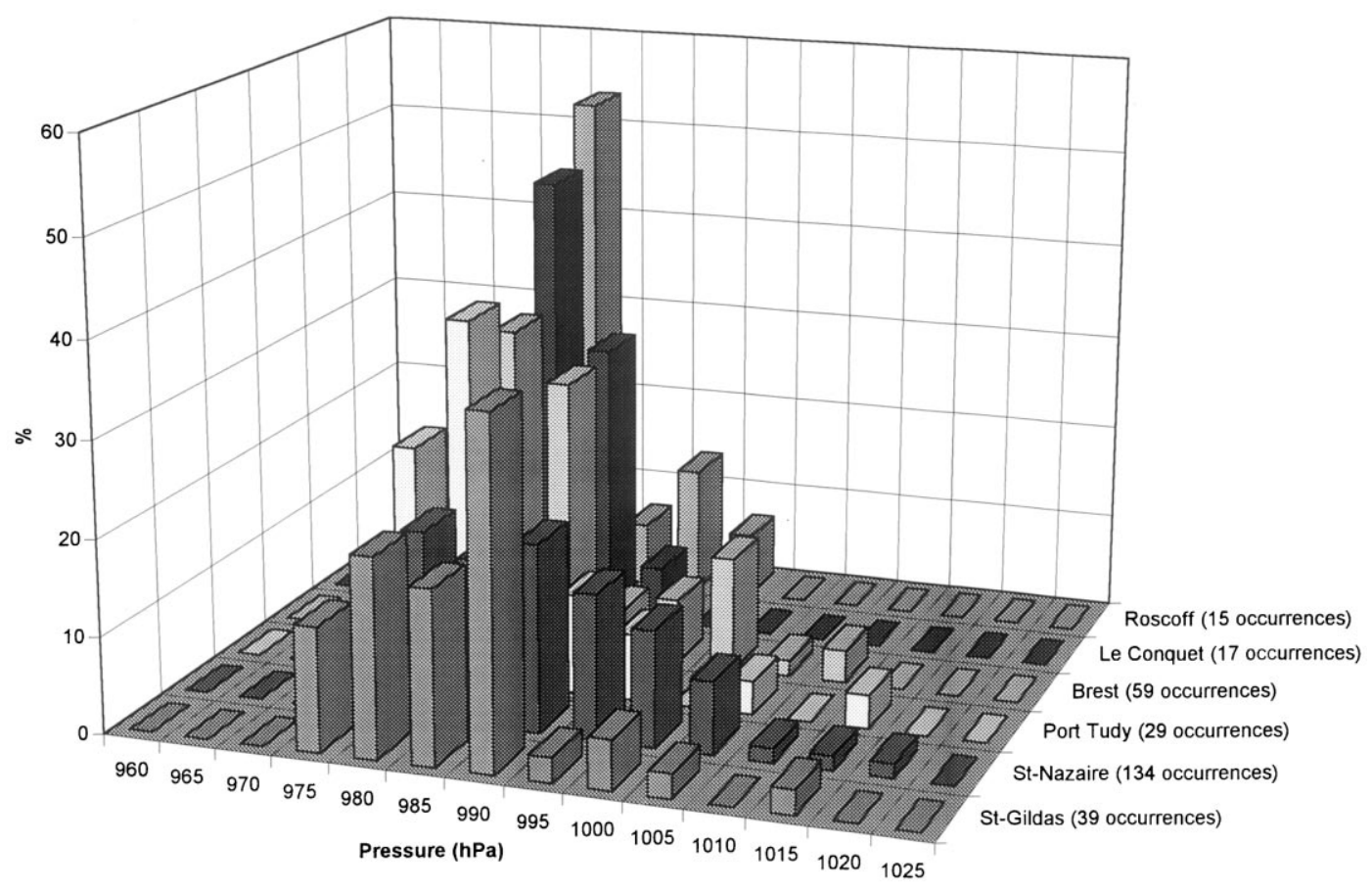

Figure 5. Air pressure at Belle-Ile at the time of surges $\geq 70 \mathrm{~cm}$ along the French Atlantic coast.

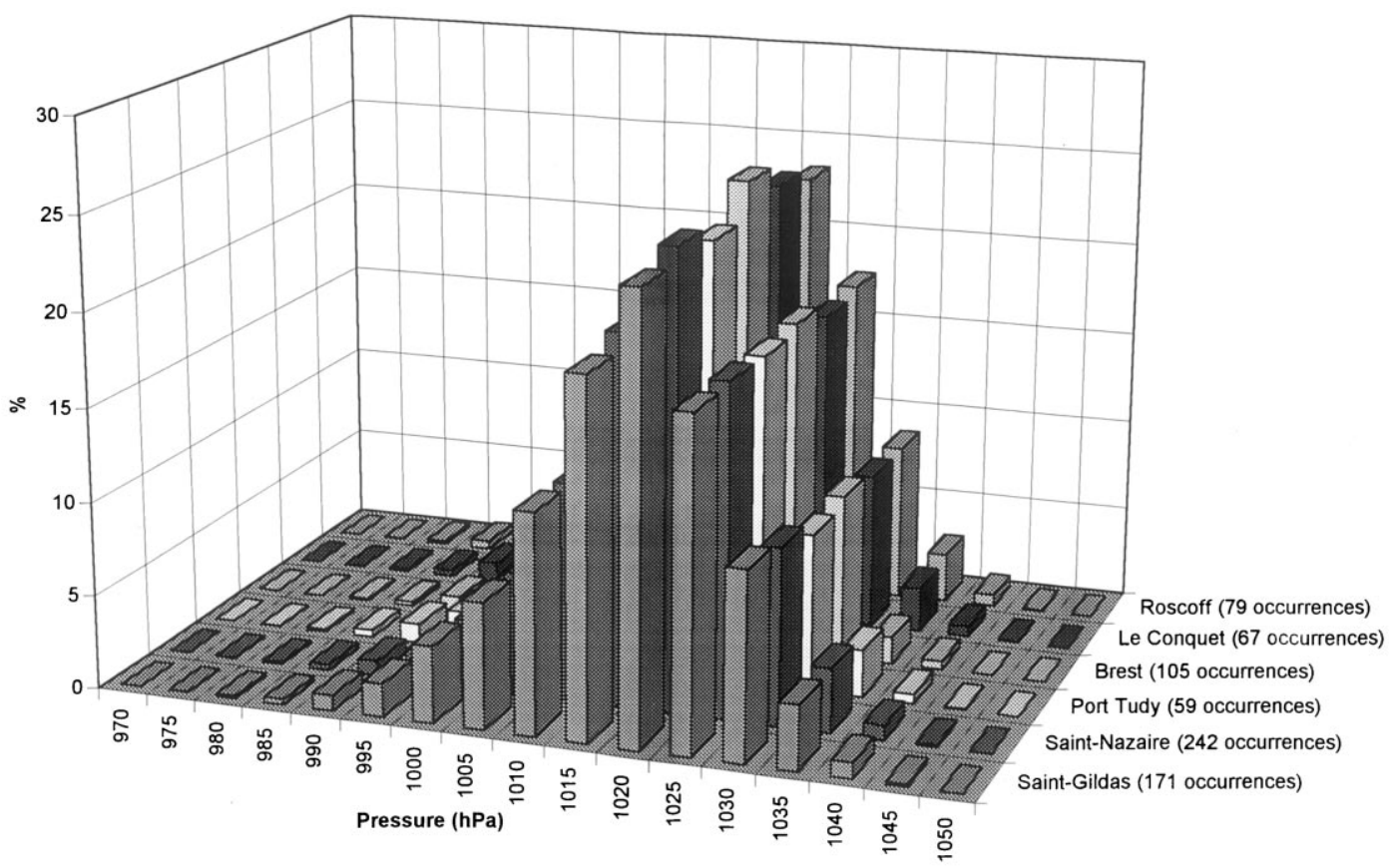

Figure 6. Air pressure at Belle-Ile at the time of negative surges $\leq-40 \mathrm{~cm}$ along the French Atlantic coast. 


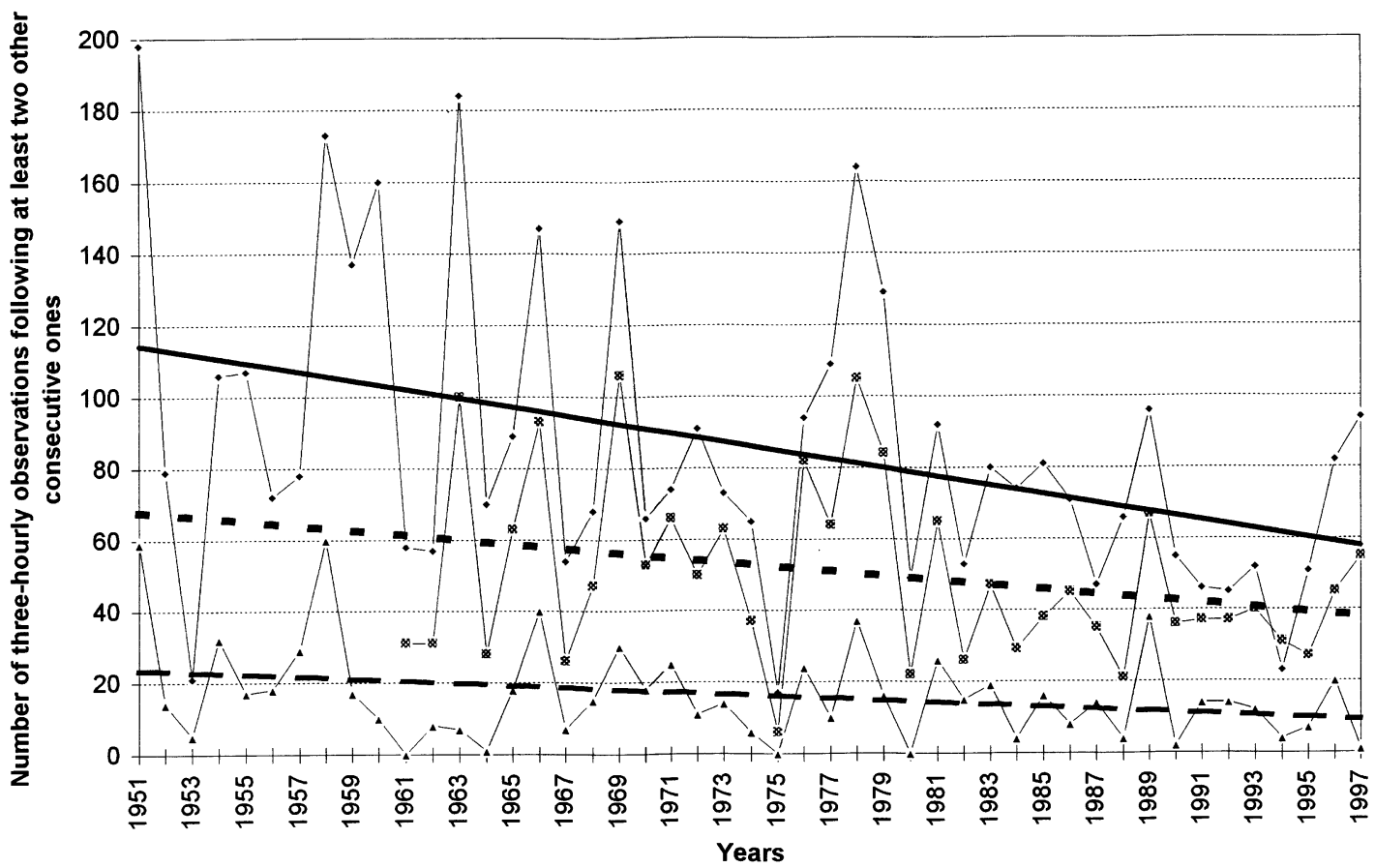

\begin{tabular}{|c|c|}
\hline $\begin{array}{l}\text { - Ouessant }<=995 \mathrm{hPa} \\
- \text { Ouessant }<=985 \mathrm{hPa} \\
- \text { Regr. (Belle-lle }<=995)=-0.65+/-0.37 \mathrm{obs} . / \mathrm{yr}\end{array}$ & $\begin{array}{l}-* \text { Belle-lle }<=995 \mathrm{hPa} \\
- \text { Regr. (Ouessant }<=995 \text { ): }-1.23+/-0.43 \mathrm{obs} . / \mathrm{yr} \\
- \text { Regr. (Ouessant }<=985 \text { ): }-0.31+/-0.14 \mathrm{obs} . / \mathrm{yr}\end{array}$ \\
\hline
\end{tabular}

Figure 7. Frequency of atmospheric depressions lasting at least 9 h below given values at Ouessant (1951-1997) and Belle-Ile (1961-1997).

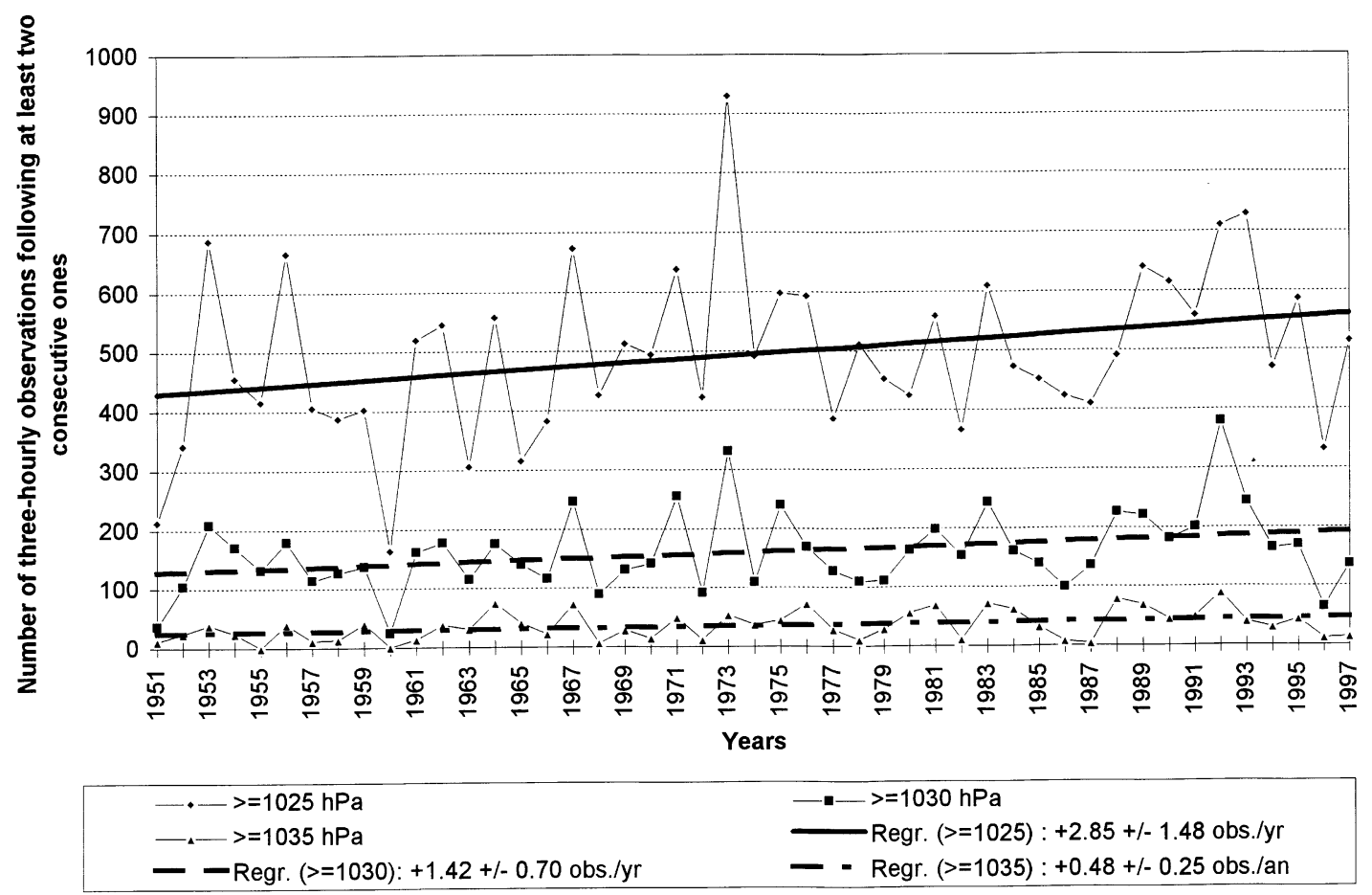

Figure 8. Frequency of atmospheric high pressure lasting at least $9 \mathrm{~h}$ above given values at Ouessant (1951-1997). 
which remained below the values of 995 or $985 \mathrm{hPa}$ during at least three consecutive three-hourly measurements. All the decreasing trends reported in figure 7 are statistically significant at over $90 \%$ (the confidence level exceeds $99 \%$ for measurements below $995 \mathrm{hPa}$ at Ouessant). Such trends are favourable to decreasing surge frequency and duration.

High pressure changes show an opposite trend, with very likely $(P \geq 0.9)$ increasing tendencies at Ouessant, for measurements above 1025,1030 and $1035 \mathrm{hPa}$ and duration of at least nine hours (figure 8 ).

In figure $9 A-C$, the normal distribution of wind directions at Belle-Ile is summarised for all winds (about 119000 three-hourly measurements), for 243 occurrences of three-hourly velocities $\geq 20 \mathrm{~m} \cdot \mathrm{s}^{-1}$ and for the maximum daily gust velocity $\geq 30 \mathrm{~m} \cdot \mathrm{s}^{-1}$. In the following six graphs (figure $9 D-I$ ), the wind distribution corresponds to that recorded at the time of hourly surges higher or equal than 70 to $100 \mathrm{~cm}$ and during the eight preceding hours at Saint-Gildas, SaintNazaire, Port Tudy, Brest, Le Conquet and Roscoff, respectively. The most frequent surge-associated wind directions at Belle-Ile are clearly from SW $\left(180^{\circ}-260^{\circ}\right)$ and usually correspond to the strongest wind events. Strong winds from WNW $\left(280^{\circ}-320^{\circ}\right)$ are not rare, but their contribution to surges usually remains small. The last six graphs (figure 9J-O) show the wind distribution at the time of negative surges lower than or equal to $-40 \mathrm{~cm}$ at the same tide-gauge stations. The most frequent negative-surge associated winds are roughly northerlies (between $320^{\circ}$ and $80^{\circ}$ ).
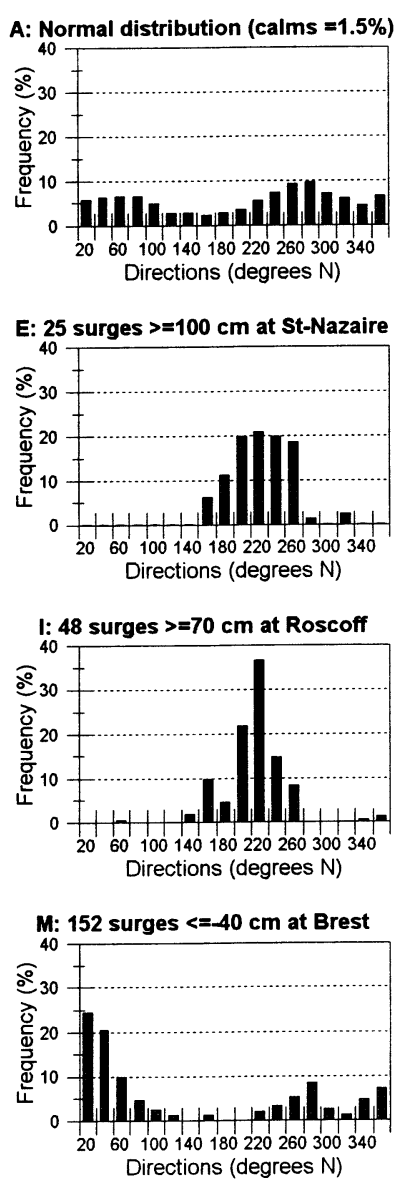
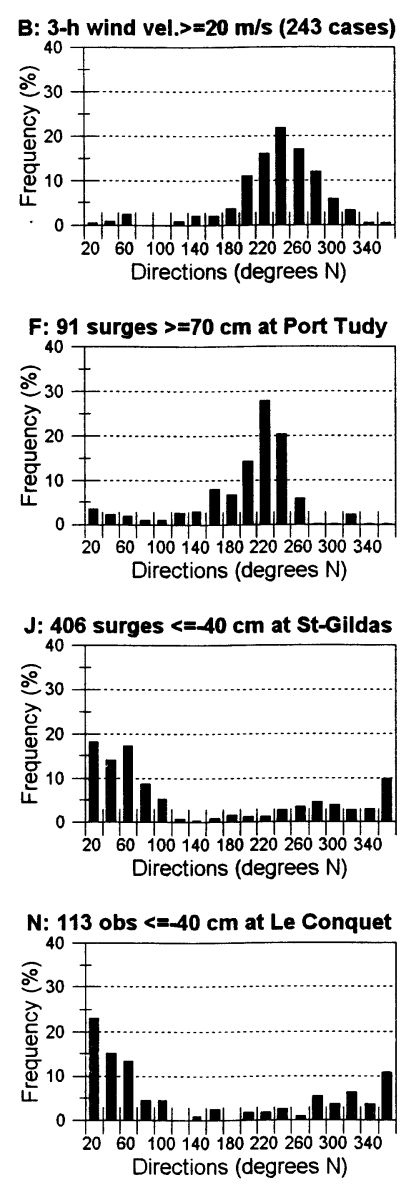
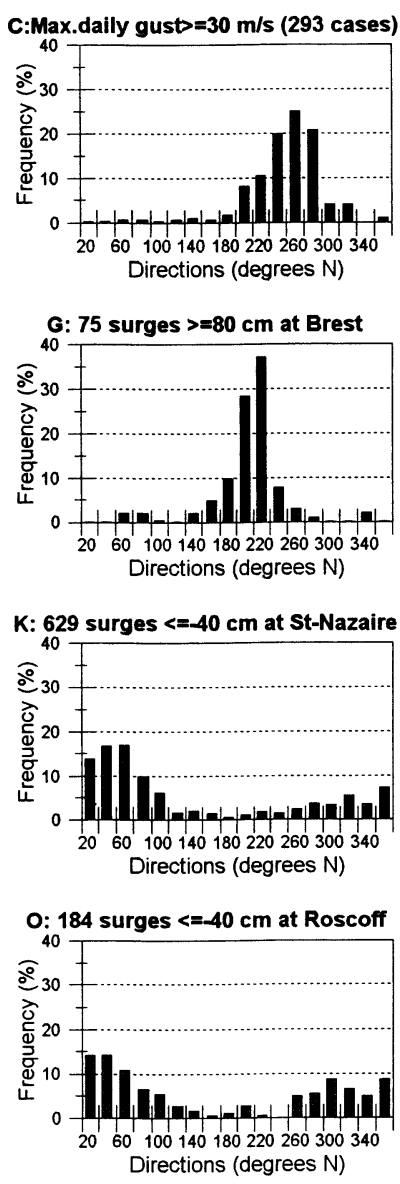
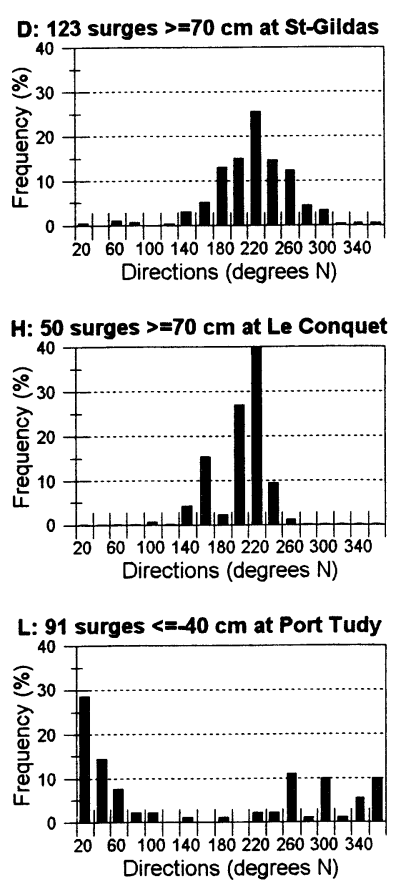

Figure 9. Wind directions at Belle-Ile: normal three-hourly distribution; three-hourly winds with velocity $\geq 20 \mathrm{~m} \cdot \mathrm{s}^{-1}$; maximum daily gusts with velocity $\geq 30 \mathrm{~m} \cdot \mathrm{s}^{-1}$; at the time of surges and during the eight preceding hours at Saint-Gildas, Saint-Nazaire, Port Tudy, Brest, Le Conquet and Roscoff; and at the time of negative surges $\leq-40 \mathrm{~cm}$ at the same stations. 
In a similar way, wind directions at Ouessant (over 150000 three-hourly measurements) are summarised in figure 10. The range of strong wind directions appears wider at Ouessant than at Belle-Ile. For the nearest tide-gauge stations (Brest, Le Conquet and Roscoff) the surge-associated wind directions are again from SW (mainly $160^{\circ}-240^{\circ}$ ) (figure 10G-I), whereas for Saint-Gildas, Saint-Nazaire and Port Tudy (figure $10 D-F$ ) correlation with surge-associated wind directions are less clear than at Belle-Ile. Interestingly, the surge-associated wind directions at Roscoff are also from SW (figure 10I), like on the open Atlantic coast, despite the relatively sheltered position of the site from such winds. This suggests that surges are a regional rather than local phenomenon in this area, reaching near Roscoff elevations which are only slightly lower than on the
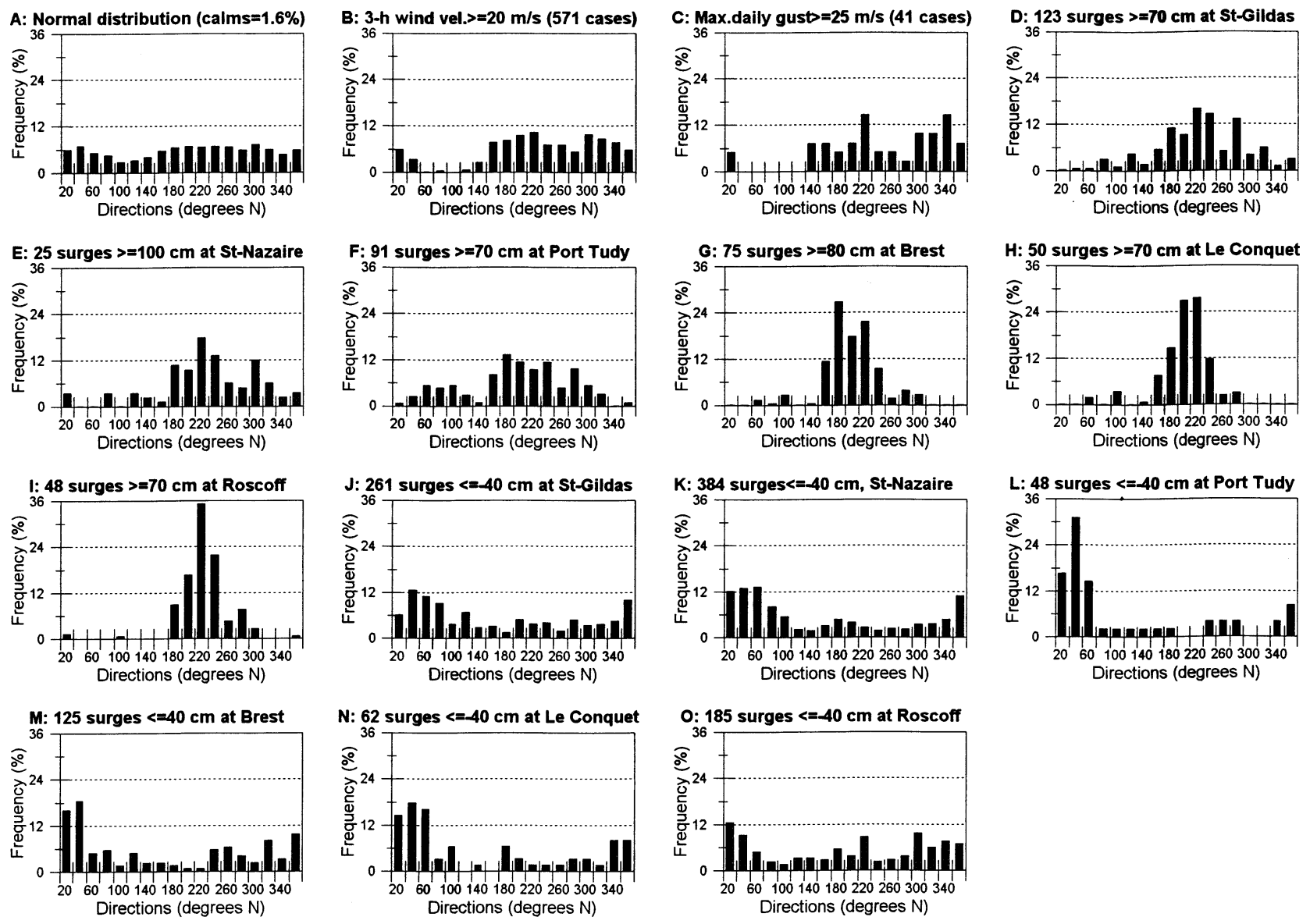

open coast. Again, the most frequent negativesurge winds are roughly northerlies (between $320^{\circ}$ and $80^{\circ}$ ). Prevailing wind directions at other stations of Brittany have been summarised by Lemasson and Regnauld [8].

A typical situation for the development of surge-assoAted wind on the Atlantic coast of France is when near southern Spain or Morocco and a depression in the North Atlantic approaching the British Isles or the Channel area (figure 11).

The recent evolution of surge-associated wind frequency, expressed as a percentage of all observations, is summarised in figure 12. In both Ouessant and Belle-Ile surge-associated winds are becoming less frequent $(P>0.99)$, corresponding to less frequent

Figure 10. Wind directions at Ouessant: normal three-hourly distribution; three-hourly winds with velocity $\geq 20 \mathrm{~m} \cdot \mathrm{s}^{-1}$; maximum daily gusts with velocity $\geq 25 \mathrm{~m} \cdot \mathrm{s}^{-1}$; at the time of surges and during the eight preceding hours at Saint-Gildas, Saint-Nazaire, Port Tudy, Brest, Le Conquet and Roscoff; and at the time of negative surges $\leq-40 \mathrm{~cm}$ at the same stations. 


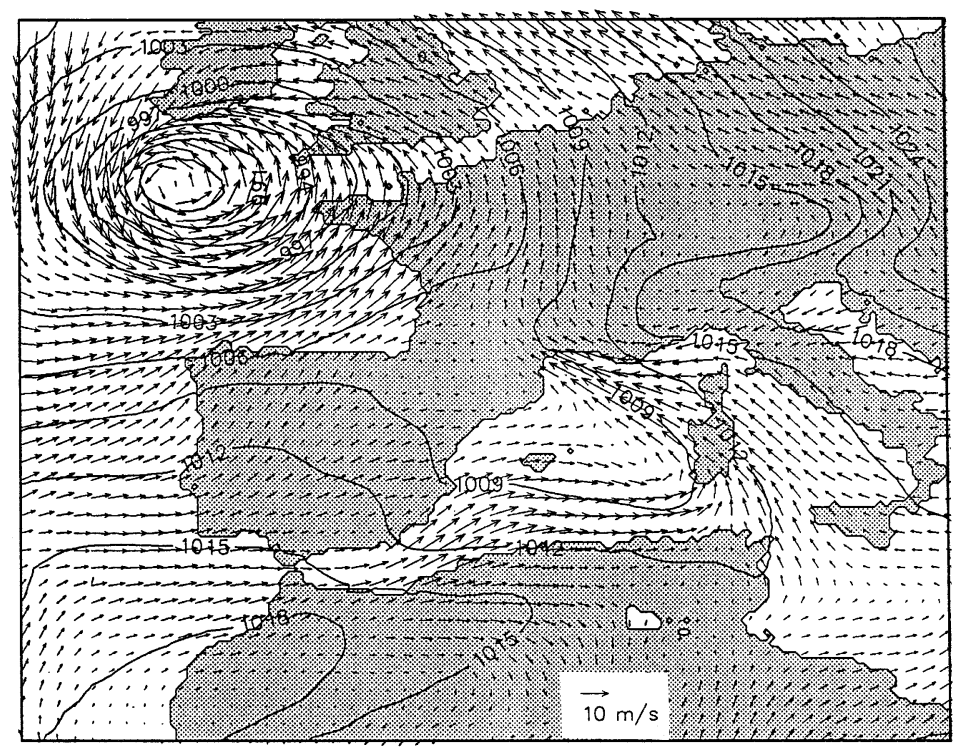

Figure 11. Air pressure, wind direction and velocity on 4 November 1997 at 12 h, according to the ECMWF model, Reading (courtesy Consorzio Venezia Nuova and Centro Previsioni e Segnalazioni Maree, Venice), showing a detailed wind distribution pattern. Three-hourly wind records at the same moment indicate at Belle-Ile a velocity of $14 \mathrm{~m} \cdot \mathrm{s}^{-1}$ from $220^{\circ}$ and at Ouessant a velocity of $12 \mathrm{~m} \cdot \mathrm{s}^{-1}$ from $180^{\circ}$.

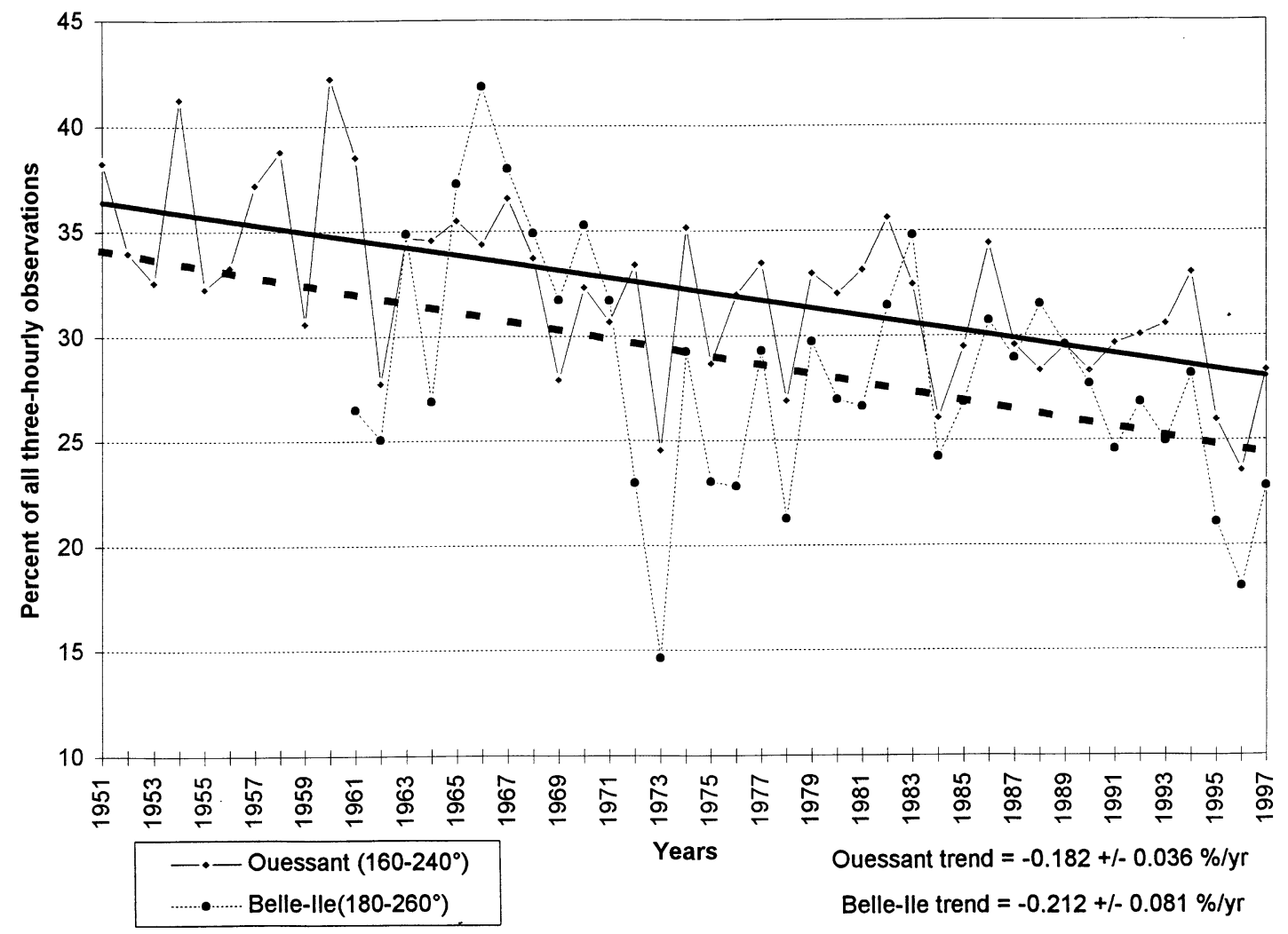

Figure 12. Surge event related wind frequency as a \% of all observations at Ouessant (1951-1997) and Belle-Ile (1961-1997). 


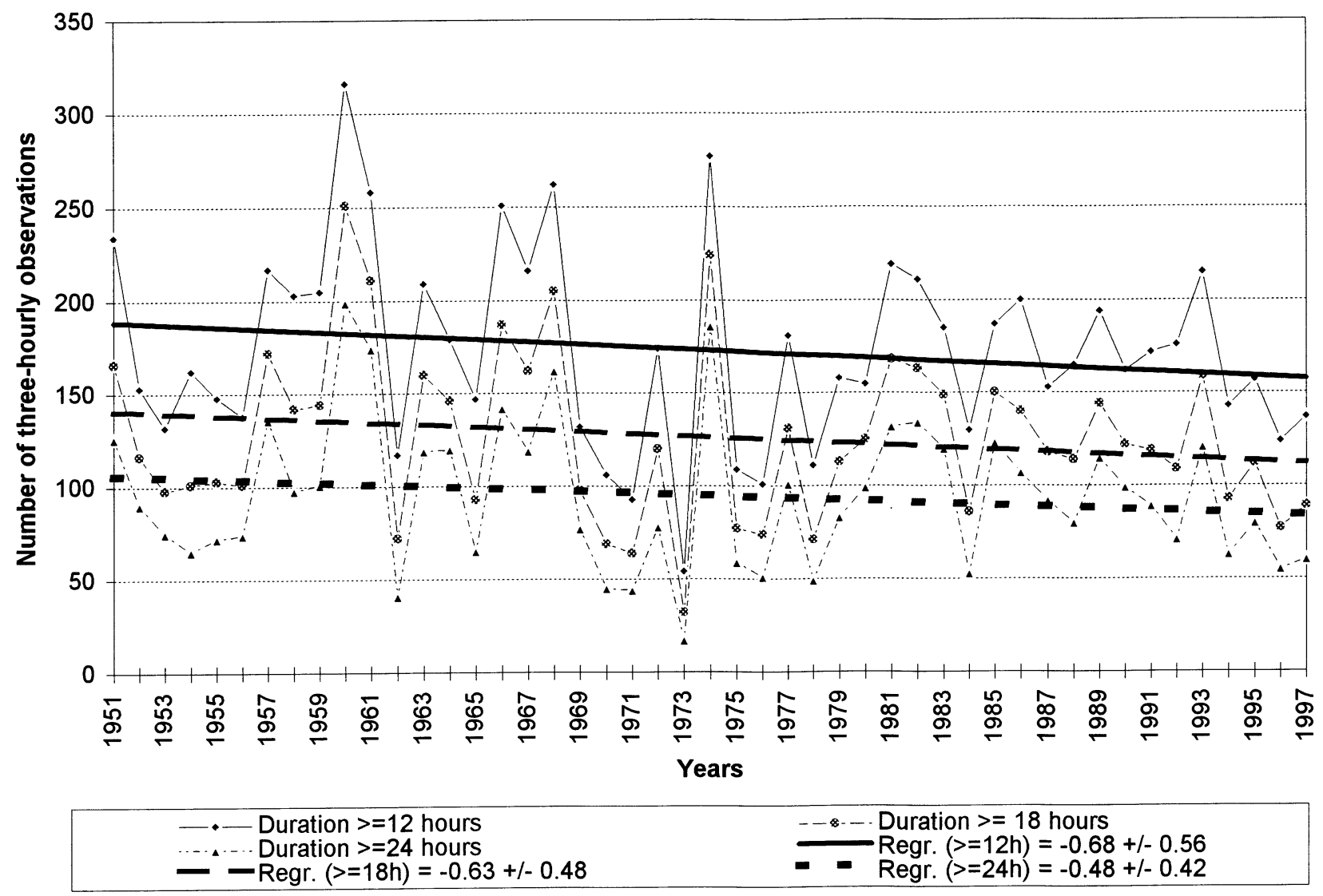

Figure 13. Frequency of surge related wind with directions between $160^{\circ}$ and $240^{\circ}$ and velocities $\geq 10 \mathrm{~m} \cdot \mathrm{s}^{-1}$ lasting $\geq 12 \mathrm{~h}$, $\geq 18 \mathrm{~h}$ and $\geq 24 \mathrm{~h}$ at Ouessant (1951-1997).

cyclonic situations [7]. Such decreasing trends are mainly due to lesser duration of persistent strong winds, which are the main contributors to surge development (figure 13). The number of three-hourly observations corresponding to duration e.g. $\geq 12 \mathrm{~h}$ in figure 13 has been obtained by counting all the measurements at Ouessant with wind $\geq 10 \mathrm{~m} \cdot \mathrm{s}^{-1}$ from $160^{\circ}-240^{\circ}$ which were preceded by at least three consecutive three-hourly measurements with similar velocity and direction.

While surge-associated winds tend to be less frequent and last less time, their velocities tend to increase slightly at Ouessant, as reported in figure 14 for the maximum and the 95th percentile of the daily maximum gust, as well as the maximum, the 95th percentile and the mean of all three-hourly measurements with wind directions between $160^{\circ}$ and $240^{\circ}$. All the trends indicate a likely $(P>0.68)$ slight increase for the three-hourly values considered.
To summarise, surges show a slightly decreasing trend during the last few decades (figure 4) and such a trend may be ascribed to a gradual change in climate: atmospheric depressions are becoming less frequent (figure 7), strong surge-generating winds are also becoming less frequent (figure 12) and occur with less duration (figure 13). Though surge-wind velocity tends to increase slightly (figure 14) this effect is not sufficient to invert the general tendency towards a decrease in surges. Such trends cannot be extrapolated into the past (as specified above, surges at Brest show increasing trends from 1860 to 1944) and it is not known whether they will be progressive in the future; however they may be linked to changes in storm activity and shifts in the Atlantic storm track related to the trend in the North Atlantic Oscillation over the last few decades [5].

If negative-surge winds are considered, their indications are contradictory: those at Belle-Ile suggest a 


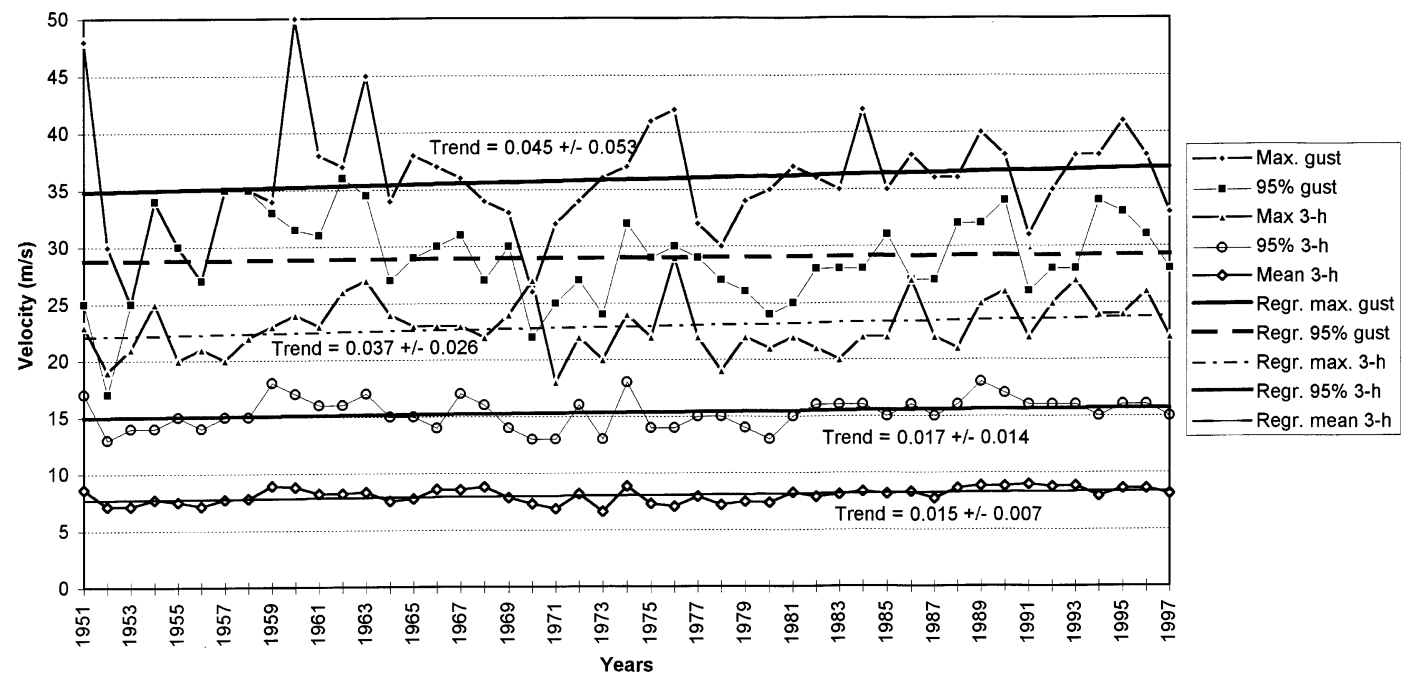

Figure 14. Evolution of surge wind $\left(160^{\circ}-240^{\circ}\right)$ velocities at Ouessant: maximum daily gust, 95 th percentile of maximum daily gusts, maximum three-hourly measurement, 95th percentile of three-hourly measurements, and mean of three-hourly measurements.

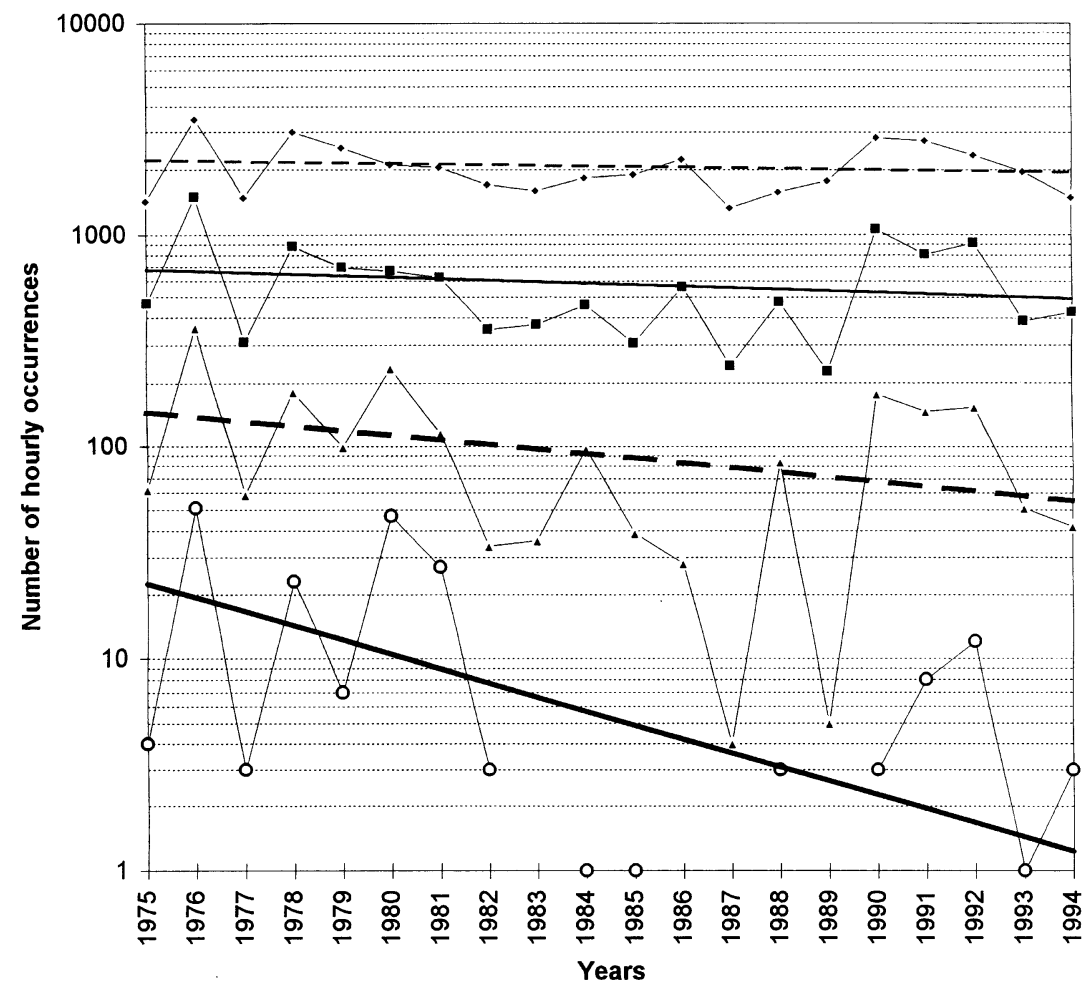

\begin{tabular}{|ll}
$-1-<=-10 \mathrm{~cm}$ & $-<=-20 \mathrm{~cm}$ \\
$-<=-30 \mathrm{~cm}$ & $-<=-40 \mathrm{~cm}$ \\
--- Regr. $(<=-10 \mathrm{~cm}):-13.6+/-23.2$ & Regr. $(<=-20 \mathrm{~cm}):-9.7+/-12.5$ \\
- Regr. $(<=-30 \mathrm{~cm}):-4.78+/-3.36$ & Regr. $(<=-40 \mathrm{~cm}):-1.19+/-0.54$
\end{tabular}

Figure 15. Semi-logarithmic representation of the frequency of negative surges ( $\leq-10$ to $\leq-40 \mathrm{~m})$ at Port Tudy (1975-1994). 
decrease in frequency, duration and velocity since 1961, whereas those at Ouessant suggest a slight increase since 1951. Nevertheless, in contrast to increasing high air pressure duration (figure 8 ), which is favourable to negative surge development, negative surges may tend to become less frequent and less low. At Brest, Bouligand and Pirazzoli [3] have found that the level of the lowest annual negative surge has been rising since 1953 at the rate of $4.1 \pm 1.3 \mathrm{~mm} \cdot \mathrm{yr}^{-1}$ and that a similar rising trend exists for the level of the 2nd percentile of negative surges. In other stations of the French Atlantic coast, where the data available are less complete than at Brest, similar trends can be observed over shorter periods; at Port Tudy, for example, the frequency of negative surges has been decreasing between 1975 and 1994 and such a decrease can be considered likely $(P>0.8)$ for surges $\leq-30$, and very likely $(P>0.96)$ for surges $\leq-40$ $\mathrm{cm}$ (figure 15).

\section{THE PROBABILITY OF COASTAL FLOODS}

It has been shown in table II that the maximum recorded tide levels (in which astronomical tides and surges are superimposed) do not exceed the maximum astronomical tide by more than 16 to $32 \mathrm{~cm}$ at any station of the French Atlantic coast, whereas maximum recorded surges have been much higher $(98$ to $173 \mathrm{~cm}$ ). This indicates that during the considered periods the highest surges did not occur at the time of very high astronomical tides. To emphasise the impact of this last point, a comparison between two case studies will be made.

A first remarkable case study is that of 11-12 May 1983 at Saint-Gildas and Saint-Nazaire (figure 16). On 11 May air pressure remained relatively low. A minimum value below $990 \mathrm{hPa}$ was reached both at Belle-Ile and Ouessant on 12 May at about 3 am (figure 16A). Three-hourly wind velocity of 10-14 $\mathrm{m} \cdot \mathrm{s}^{-1}$ occurred on 11 May, with a maximum gust of $24 \mathrm{~m} \cdot \mathrm{s}^{-1}$ from $240^{\circ}$ at Belle-Ile and of $26 \mathrm{~m} \cdot \mathrm{s}^{-1}$ from $280^{\circ}$ at Ouessant. The surge produced by these meteorological factors reached at 3 am a maximum height of $110 \mathrm{~cm}$ at Saint-Nazaire and $87 \mathrm{~cm}$ at SaintGildas; without being exceptional (table II), these values are relatively high. At Saint-Nazaire the surge peak was followed by a single oscillation of about half a metre, with a period of about $11-12 \mathrm{~h}$, resem- bling a seiche, which however was not observed at Saint-Gildas, just outside the Loire estuary. Such an oscillation, which may be related to hydrodynamic processes in the estuary, completely disappears by smoothing the surge-values with $12 \mathrm{~h}$ running means. These show almost identical surge patterns at the two stations (figure 16B). The surge peak occurred about one hour before a non-exceptional but relatively high astronomical spring high tide $(532 \mathrm{~cm}$ predicted at Saint-Nazaire at 4:10 am), thus producing a recorded tide level of $629 \mathrm{~cm}$, which has been overtopped at Saint-Nazaire only once $(634 \mathrm{~cm})$, on 31 December 1978, in similar astronomical and surge conditions. The surge peaks of 11 May 1983 and of 31 December 1978 were much smaller than many other surges recorded in the area (table II); however, because they occurred close to an astronomical spring high tide, they were sufficient to produce extreme recorded tide levels.

A second remarkable case study is that of 16 October 1987. Its meteorological situation has been analysed by several authors (e.g. [2, 9]). The air pressure and tidal evolution are summarised in figure 17. A deep atmospheric depression reached the Brittany area at the end of 15 October, with a minimum of $974 \mathrm{hPa}$ at Belle-Ile and $961 \mathrm{hPa}$ at Ouessant (figure 17A). Three-hourly wind measurements recorded stronger winds at Belle-Ile, with six consecutive mean velocities between 18 and $25 \mathrm{~m} \cdot \mathrm{s}^{-1}$ from $200^{\circ}-240^{\circ}$ on 15 October, whereas mean velocities of three-hourly measurements did not exceed $15 \mathrm{~m} \cdot \mathrm{s}^{-1}$ at Ouessant. The maximum wind gust reached on 15 October was $45 \mathrm{~m} \cdot \mathrm{s}^{-1}$ from $220^{\circ}$ at Belle-Ile and $36 \mathrm{~m} \cdot \mathrm{s}^{-1}$ from $200^{\circ}$ at Ouessant and on 16 October $36 \mathrm{~m} \cdot \mathrm{s}^{-1}$ from $220^{\circ}$ at Belle-Ile and $49 \mathrm{~m} \cdot \mathrm{s}^{-1}$ from $320^{\circ}$ at Ouessant. The surge produced by the above events was an extreme one (144 cm at Brest, $143 \mathrm{~cm}$ at Le Conquet, $129 \mathrm{~cm}$ at Port Tudy) (figure 17B); the surge peak, in spite of its short duration, also coincided with an astronomical high tide, but fortunately it was the day after a neap tide, so that the total recorded level remained well below the highest astronomical levels at the three stations (figure 17C) and no flood damage occurred (except for that produced by waves).

To estimate the probability of flooding events at Brest, the frequencies of the surge and of the astronomical components of the tide have been computed separately, following a method already applied to 

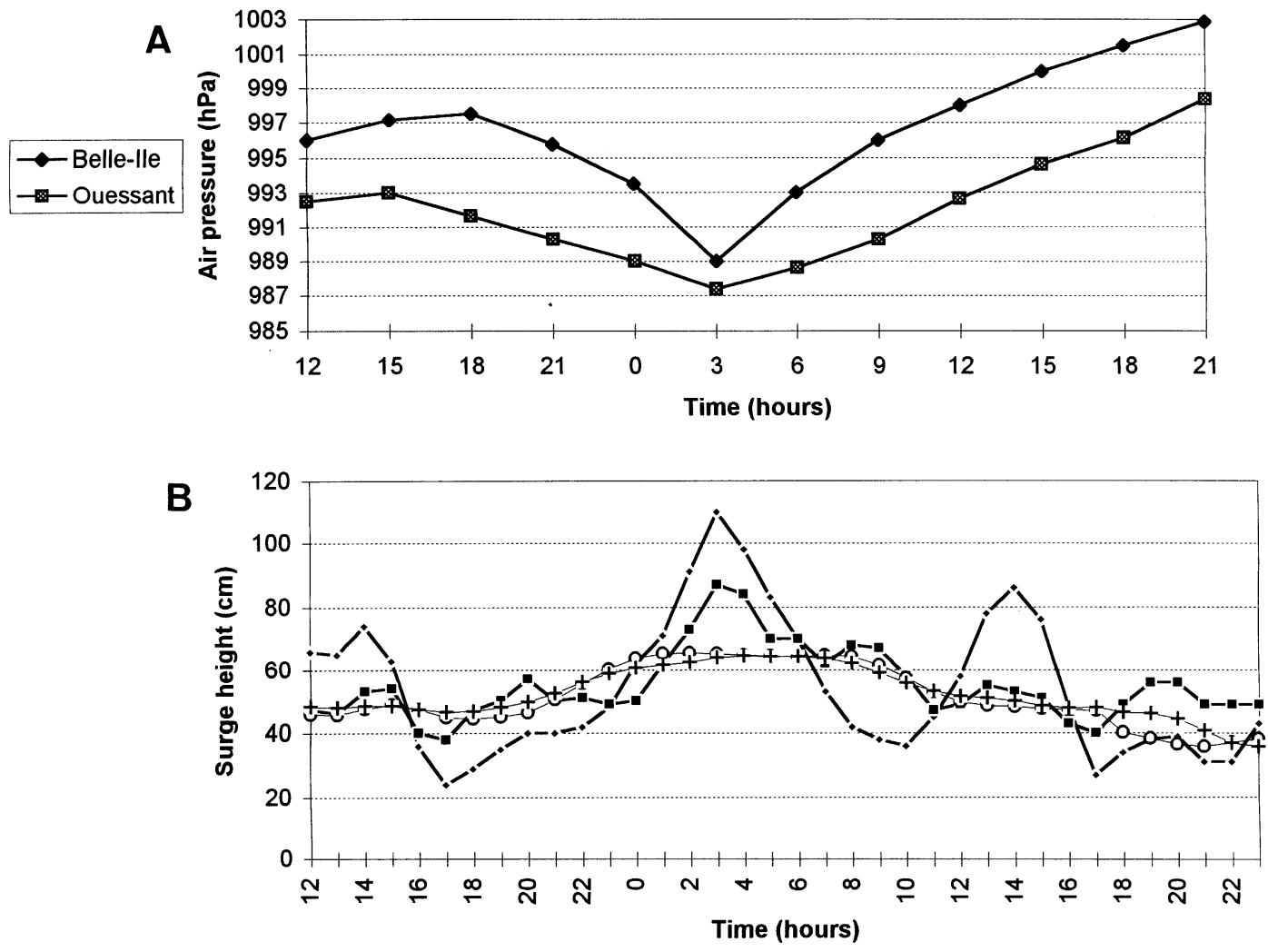

$-\cdot-$ St-Nazaire (apparent surge) --- St-Gildas (apparent surge)
$-0-$ St-Nazaire (12h surge mean) + St-Gildas (12h surge mean)

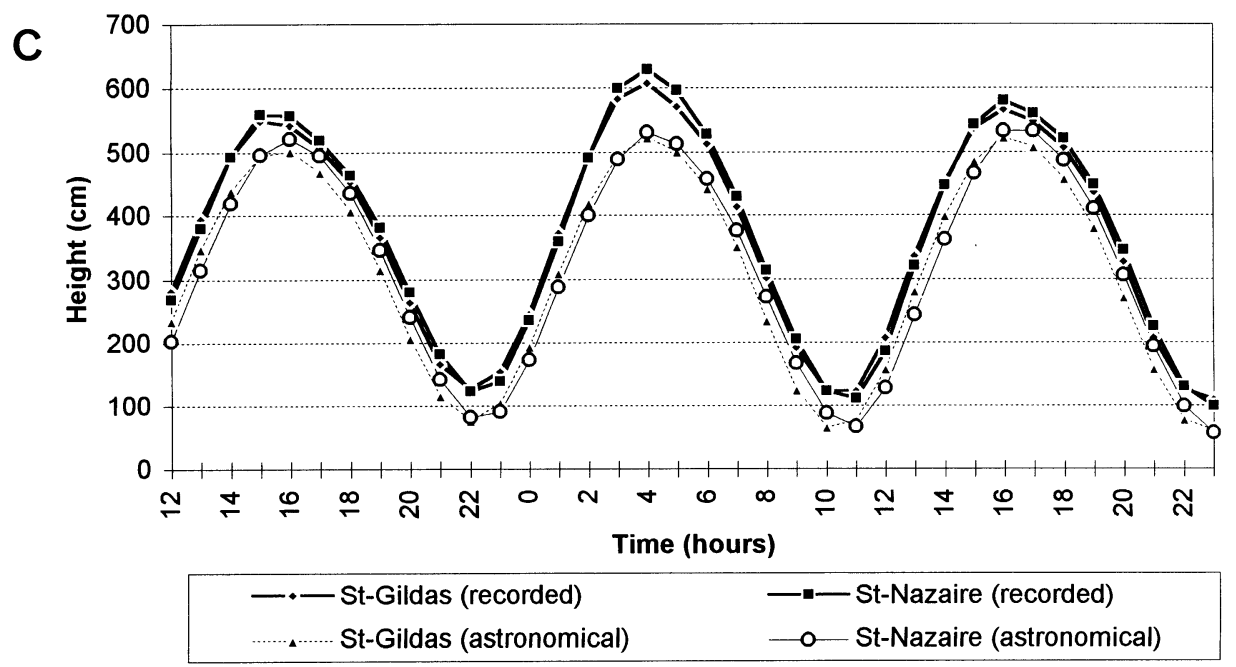

Figure 16. The surge of 11-12 May 1983. A) Surface air pressure at Belle-Ile and Ouessant. B) Observed surge at Saint-Gildas and Saint-Nazaire and 12-h smoothed surge values. C) Observed and predicted tidal elevations at Saint-Gildas and Saint-Nazaire. 

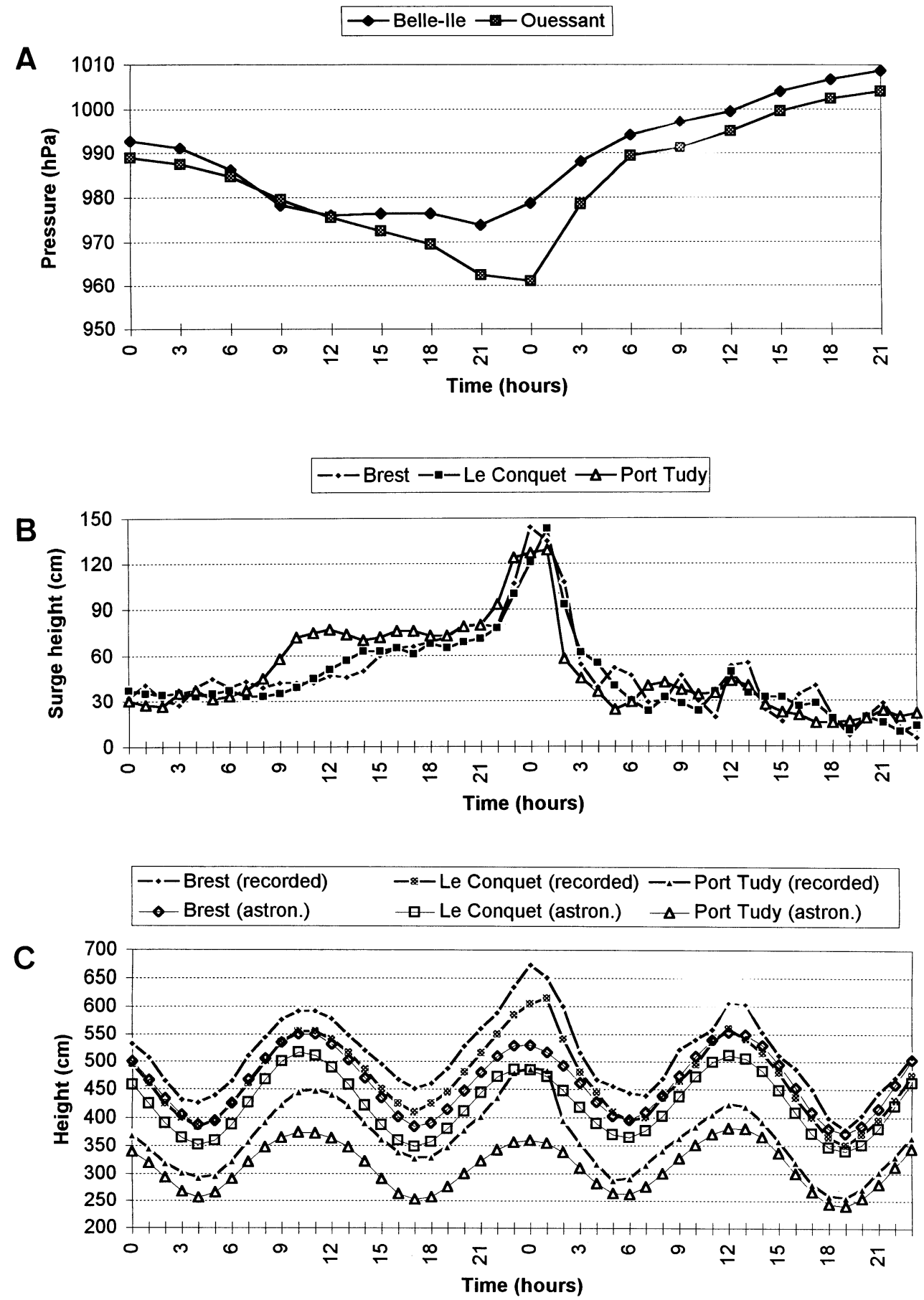

Figure 17. The surge of 15-16 October 1987. A) Surface air pressure at Belle-Ile and Ouessant. B) Observed surge at Brest, Le Conquet and Port Tudy. C) Observed and predicted tidal elevations at Brest, Le Conquet and Port Tudy. 

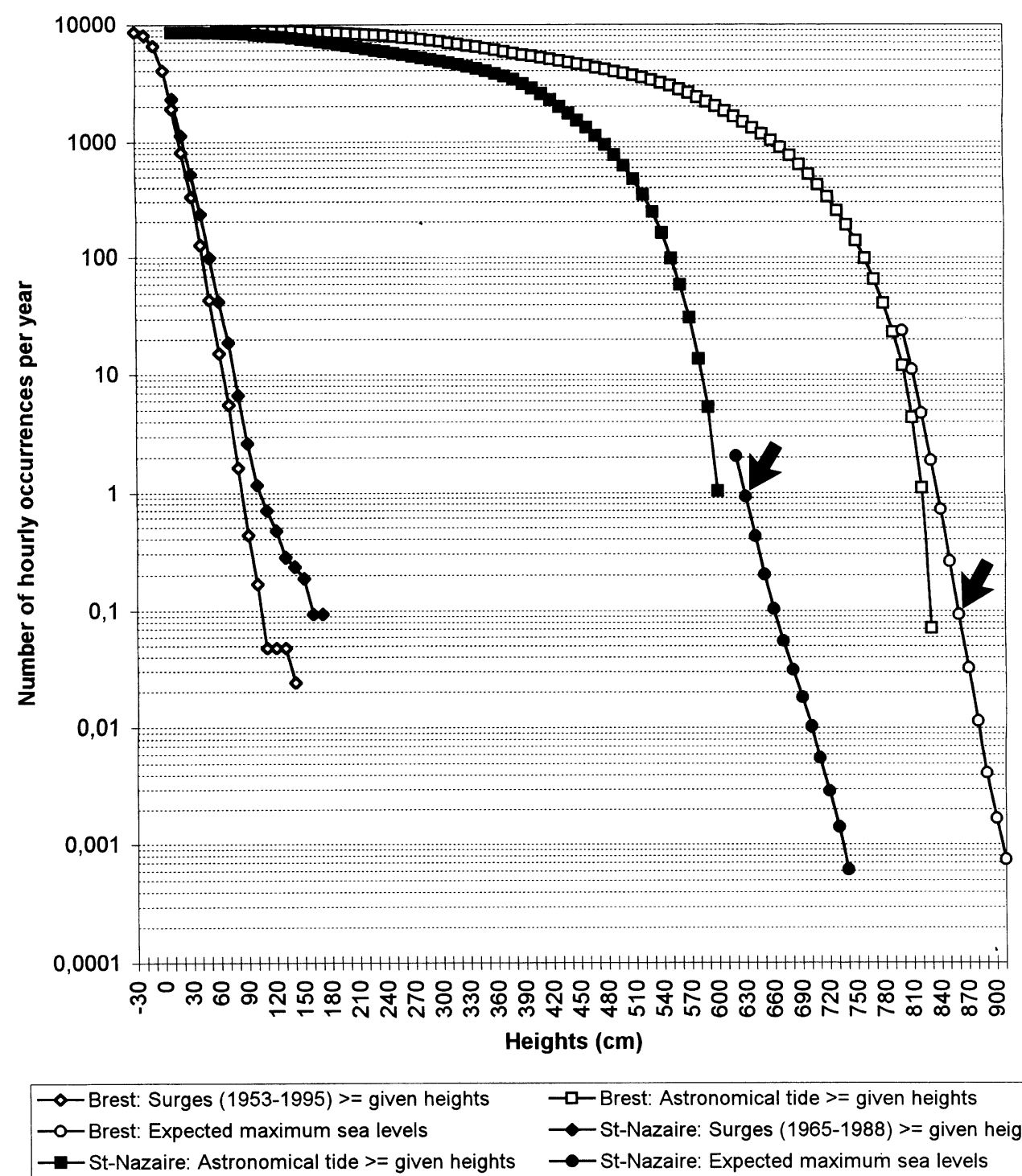

$\rightarrow$ - Brest: Astronomical tide $>=$ given heights

$\multimap$ St-Nazaire: Surges $(1965-1988)>=$ given heights

$\longrightarrow$ St-Nazaire: Expected maximum sea levels

Figure 18. Yearly frequency of hourly tidal heights greater than or equal to given levels at Brest and Saint-Nazaire: recorded surges, astronomical tide, and expected maximum sea levels; arrows correspond to the maximum sea levels recorded during the periods considered.

high tide values [13]. The probability of surge values has been deduced from the available sample of recorded data. The application of extrapolating methods (such as the Gumbel method, already used in previous papers $[3,13])$, would have probably refined the probability of extremely rare events, without however modifying the conclusions of this section.
The probability of occurrence of tide levels higher than the maxima recorded at Brest between 1953 and 1995 has subsequently been computed, by combining the probabilities of the astronomical and the surge components, and plotted in figure 18. A comparison between the number of occurrences recorded at the highest levels and those statistically expected as prob- 
Table III. Occurrences of high and low levels of the astronomical tide (AT) at the time of extreme surges.

\begin{tabular}{|c|c|c|c|c|c|c|c|c|}
\hline \multirow{2}{*}{$\begin{array}{l}\text { Tide-gauge } \\
\text { station }\end{array}$} & \multirow{2}{*}{$\begin{array}{l}95 \text { th } \\
\text { percentile } \\
\text { of AT }(\mathrm{cm})\end{array}$} & \multirow{2}{*}{$\begin{array}{l}\text { 90th } \\
\text { percentile } \\
\text { of AT }(\mathrm{cm})^{\mathrm{a}}\end{array}$} & \multicolumn{2}{|c|}{20 highest recorded surges } & \multirow{2}{*}{$\begin{array}{l}\text { 5th } \\
\text { percentile } \\
\text { of AT }(\mathrm{cm})^{\mathrm{a}}\end{array}$} & \multirow{2}{*}{$\begin{array}{l}10 \text { th } \\
\text { percentile } \\
\text { of AT }(\mathrm{cm})^{\mathrm{a}}\end{array}$} & \multicolumn{2}{|c|}{20 lowest (negative) surges } \\
\hline & & & $\begin{array}{l}\text { No. of occurrences } \\
\text { with AT } \geq 95 \text { th } \\
\text { percentile ( } 1 \text { occur- } \\
\text { rence expected) }\end{array}$ & $\begin{array}{l}\text { No. of occurrences } \\
\text { with AT } \geq 90 \text { th } \\
\text { percentile }(2 \text { occur- } \\
\text { rences expected) }\end{array}$ & & & $\begin{array}{l}\text { No. of occurrences } \\
\text { with AT } \leq 5 \text { th } \\
\text { percentile ( } 1 \text { occur- } \\
\text { rence expected) }\end{array}$ & $\begin{array}{l}\text { No. of occurrences } \\
\text { with AT } \leq 10 \text { th } \\
\text { percentile ( } 2 \text { occur- } \\
\text { rences expected })\end{array}$ \\
\hline Saint-Nazaire & +513 & +485 & 0 & 1 & +98 & +131 & 4 & 6 \\
\hline Port Tudy & +486 & +461 & 0 & 0 & +125 & +155 & 0 & 0 \\
\hline Brest (1860-1995) & +700 & +663 & 1 & 1 & +204 & +242 & 1 & 3 \\
\hline Brest (1953-1995) & +708 & +671 & 0 & 2 & +210 & +248 & 1 & 4 \\
\hline Le Conquet & +666 & +629 & 0 & 2 & +175 & +211 & 0 & 0 \\
\hline Roscoff & +840 & +799 & 0 & 1 & +189 & +239 & 0 & 1 \\
\hline
\end{tabular}

${ }^{\text {a }}$ In relation to local datums.

able at the same levels (figure 18) demonstrates that the number of highest recorded levels has been systematically smaller than expected at Brest. For example, 150 hourly levels $\geq 820 \mathrm{~cm}$ have been recorded; in comparison, the number of expected hourly occurrences $\geq 820 \mathrm{~cm}$ (4.72 times per year according to figure 18) is 198 for all the data available between 1953 and 1995. In the same way, 54 hourly levels have been recorded $\geq 830 \mathrm{~cm}$ (70 expected), 18 recorded levels $\geq 840 \mathrm{~cm}$ (27 expected), 6 recorded levels $\geq 850 \mathrm{~cm}$ (10 expected), and no recorded level $\geq 860 \mathrm{~cm}$ ( 3.5 cases expected $\geq 860 \mathrm{~cm}$ and even 1.1 case $\geq 870 \mathrm{~cm})$.

Similar probability curves have been constructed for each tidal station of the French Atlantic coast, with similar results. At Saint-Nazaire (figure 18), 32 hourly tide levels $\geq 620 \mathrm{~cm}$ were recorded from 1965 to 1988 (43 cases expected), 1 record $\geq 630 \mathrm{~cm}$ (20 cases expected) and no record $\geq 640 \mathrm{~cm}$ (whereas 9 events were expected $\geq 640 \mathrm{~cm}, 4.2$ events $\geq 650 \mathrm{~cm}$, 2.1 events $\geq 670 \mathrm{~cm}$ and 1.2 events $\geq 680 \mathrm{~cm}$ ).

In conclusion there has been during the last few decades a random scarcity of high surges occurring at the time of high astronomical tide levels. This result is summarised statistically in a different way in table III, where a comparison is made, for the twenty highest surges recorded at each station, between the number of those statistically expected to occur at the time of astronomical tide levels exceeding the 90th and 95th percentiles and the number of those which actually occurred. It can be observed that none of the highest twenty surges coincided with an astronomical tide level $\geq$ the 95th percentile (whereas at least one occurrence is expected at each station) and also that the number of highest surges coinciding with an astronomical tide $\geq$ the 90th percentile is generally less than expected.

A similar comparison applied to the lowest tide shows a much more variable situation, with more extreme negative surges than expected at the time of lowest astronomical tide levels at Saint-Nazaire and Brest, and with a random scarcity of extreme events at Port Tudy, Le Conquet and Roscoff (table III).

\section{CONCLUSIONS}

This statistical analysis of tidal and meteorological records of the Atlantic coast of France has disclosed results which are reassuring but also alarming. They are reassuring because during the last few decades climate variability has produced decreasing trends in the main factors which contribute to surge development: atmospheric depressions are becoming less frequent and strong southwesterlies less frequent and lasting for shorter periods. As a consequence, and in spite of a slight increase in surge-wind velocity, the frequency of surges has been decreasing slightly. The recent trend of climate variability is therefore less favourable to coastal flooding in this region than in the past.

However during the period considered there has also been a random scarcity of high surges occurring at 
the time of high astronomical tides and this is alarming, because it appears to be due only to chance; in the near future, joint events can be expected to have a normal frequency according to statistical probabilities and the threat of an extreme surge coinciding with a spring high tide is ever present. If the great storm of 16 October 1987 (which produced the maximum recorded surge at several stations on the French Atlantic coast) had occurred at the time of a stronger astronomical tide, coastal flooding could have been as much as 1.0 to $1.5 \mathrm{~m}$ higher than any recorded level. The risk of occurrence of such random events in the near future is of concern, and may overshadow the advantages that can be expected from a favourable (but slow) change in climate.

\section{Acknowledgements}

This study was carried out with the financial contribution of the E.U. project "Storms" (DG12-VOMA: contract ENV4-CT970488). Helpful suggestions received from the anonymous referees are gratefully acknowledged.

\section{REFERENCES}

[1] Bouligand, R., Tabeaud, M., 1998. Cent ans de surcotes à Brest. MetMar 180, 12-16.

[2] Bouligand, R., Aelbrecht, D., Violeau, D., 1999. États de mer - Programme 1998: Analyse météorologique succincte de tempêtes et modélisation des états de mer extrêmes en Manche et Atlantique Nord, EDF, Direction des Études et Recherches, Rapport HE-42/99/003/B, 29 p.
[3] Bouligand, R., Pirazzoli, P.A., 1999. Les surcotes et les décotes marines à Brest, étude statistique et évolution. Oceanol. Acta 22 (2), 153-166.

[4] Cazenave, A., 1999. Les variations actuelles du niveau de la mer. C. R. Acad. Sci. Paris 329 (7), 457-470.

[5] Hurrell, J.W., 1995. Decadal trends in the North Atlantic oscillation regional temperatures and precipitation. Science 269, 676-679.

[6] Jardin M.A., Oden F., 1997. Étude des phénomènes de surcotes et décotes en mer du Nord et Atlantique de 1965 à 1985, mémoire de maîtrise en géographie, univ. Paris I.

[7] Lemasson, L., 1999. Vents et tempêtes sur le littoral de l'ouest de la France: variabilité, variation et conséquences morphologiques, thèse, université Haute Bretagne-Rennes II, pp. $1-186,1-113$.

[8] Lemasson, L., Regnauld, H., 1997. Évolution trentenaire des vents littoraux sur le Grand Ouest français. Norois 44 (175), 417-431.

[9] Mounier, J., 1989. L'ouragan du 15-16 octobre 1987 sur l'Europe du Nord-Ouest. La Géographie Physique 41, 32-40.

[10] Parkes, G.S., Ketch, L.A., O'Reilly, C.T., Shaw, J., Ruffman, A., 1999. The Saxby Gale of 1869 in the Canadian Maritimes, American Meteorological Society, 23rd Conference on Hurricanes and Tropical Meteorology (Abstracts), Dallas, Texas 10-15 January, 791-794.

[11] Pirazzoli, P.A., 1996. Sea-Level Changes: The Last 20000 Years. Wiley, Chichester, pp. 1-211.

[12] Pugh, D.T., Vassie, J.M., 1979. Extreme sea levels from tide and surge probability, Proc. 16th Coastal Engineering Conf. Hamburg. Am. Soc. Civil Eng. New York 1, 911-930.

[13] Simon B., 1994, Statistique des niveaux marins extrêmes le long des côtes de France, SHOM Brest, Rapp. ét. 001/94 DPNM, ministère de l'Équipement, $78 \mathrm{p}$.

[14] Tomasin A., Pirazzoli P.A., 1999. The seiches in the Adriatic Sea, Atti Istituto Veneto di Scienze, Lettere ed Arti 157 (II) 299-316. 